\title{
Distributions and climate effects of atmospheric aerosols from the preindustrial era to 2100 along Representative Concentration Pathways (RCPs) simulated using the global aerosol model SPRINTARS
}

\author{
T. Takemura \\ Research Institute for Applied Mechanics, Kyushu University, Fukuoka, Japan \\ Correspondence to: T. Takemura (toshi@riam.kyushu-u.ac.jp)
}

Received: 21 July 2012 - Published in Atmos. Chem. Phys. Discuss.: 16 August 2012

Revised: 21 November 2012 - Accepted: 30 November 2012 - Published: 4 December 2012

\begin{abstract}
Global distributions and associated climate effects of atmospheric aerosols were simulated using a global aerosol climate model, SPRINTARS, from 1850 to the present day and projected forward to 2100. Aerosol emission inventories used by the Coupled Model Intercomparison Project Phase 5 (CMIP5) were applied to this study. Scenarios based on the Representative Concentration Pathways (RCPs) were used for the future projection. Aerosol loading in the atmosphere has already peaked and is now reducing in Europe and North America. However, in Asia where rapid economic growth is ongoing, aerosol loading is estimated to reach a maximum in the first half of this century. Atmospheric aerosols originating from the burning of biomass have maintained high loadings throughout the $21 \mathrm{st}$ century in Africa, according to the RCPs. Evolution of the adjusted forcing by direct and indirect aerosol effects over time generally correspond to the aerosol loading. The probable future pathways of global mean forcing differ based on the aerosol direct effect for different RCPs. Because aerosol forcing will be close to the preindustrial level by the end of the 21 st century for all RCPs despite the continuous increases in greenhouse gases, global warming will be accelerated with reduced aerosol negative forcing.
\end{abstract}

\section{Introduction}

Developed countries have experienced air pollution by aerosols throughout the 20th century and the situation is now worsening in some developing countries. For example, smog in Beijing and Shanghai, China, can still be severe although it did improve around the 2008 Olympic Games (Science, 2012; Washington Post, 2012). Trans-boundary air pollution from the Asian continent to Western Japan also continues to be considerable (Yamaguchi and Takemura, 2011).

Aerosols also act as climate forcing agents through several different processes. The role of aerosol particles in altering the atmospheric radiation budget due to scattering and absorption is termed the aerosol direct effect. The first indirect effect (cloud albedo effect) involves a decrease in cloud droplet and ice crystal effective radii as the number concentration of aerosol particles acting as cloud condensation nuclei (CCN) and/or ice nuclei (IN), increases. If the liquid/ice water content is constant, this will lead to a higher cloud albedo (e.g. Twomey, 1974). Changes in the amounts of CCN and IN can also affect the liquid/ice water content of clouds, which is the second indirect effect (cloud lifetime effect). A decrease in the cloud droplet size due to an increase in $\mathrm{CCN}$ results in an extension of cloud lifetime and then to an inhibition of precipitation (e.g. Albrecht, 1989). On the other hand, Lebsock et al. (2008) suggested from satellite observations that the higher aerosol concentration may lead to reduced liquid water path in nonprecipitating mixedphase clouds. An increase in IN has the effect of both increasing and decreasing the ice water content. As with the liquid phase, a decrease in ice crystal size due to an increase in IN may prolong a cloud's lifetime. In contrast, an increase in IN promotes the conversion of supercooled liquid water to ice crystals in mixed phase clouds. It is easier to grow ice crystals to snow than to change supercooled droplets to rain, 
which leads to a decrease in the total cloud water (Lohmann and Feichter, 2005). There is also a semi-direct effect, in which aerosols, such as black carbon (BC) and soil dust particles, absorb solar radiation and warm the surrounding atmosphere, resulting in a change in liquid/ice water content due to a change in the saturated water vapour pressure and atmospheric stabilisation (Koch and Del Genio, 2010; Takemura and Uchida, 2011). These aerosol effects cause changes in atmospheric general circulation through modifications to the radiation budget, cloud distribution, and hydrological cycle. It is therefore essential to elucidate the time evolution of global aerosol distributions to determine temporal changes in air pollution and climate change due to aerosol effects.

Radiative forcing $(\mathrm{RF})$ is a measure of the change in the radiation budget by climate forcing agents (greenhouse gases, aerosols, land use change, etc.). It is useful because it allows a comparison of the effects of various climate forcing agents on climate change even when the mechanisms affecting the climate system differ. In previous reports of the Intergovernmental Panel on Climate Change (IPCC), RF was defined as a change in net irradiance (solar plus thermal radiation in $\mathrm{Wm}^{-2}$ ) at the tropopause, after allowing for the stratospheric temperature to readjust to radiative equilibrium but with surface tropospheric temperatures and state held fixed at the unperturbed values (Forster et al., 2007). The RFs of the aerosol direct and first indirect effect relative to the preindustrial era were estimated to be -0.5 and $-0.7 \mathrm{Wm}^{-2}$ in the Fourth Assessment Report (AR4) of the IPCC (Intergovernmental Panel on Climate Change, 2007). The uncertainty in IPCC AR4 estimates of RF was only $10 \%$ for long-lived greenhouse gases, but was greater for the aerosol effects: from -0.1 to $-0.9 \mathrm{~W} \mathrm{~m}^{-2}$ for the aerosol direct effect and -0.3 to $-1.8 \mathrm{~W} \mathrm{~m}^{-2}$ for the aerosol first indirect effect. The aerosol RFs of the second indirect and semi-direct effects cannot be calculated by strictly following the IPCC definition, because these effects are changes in the tropospheric state. In the IPCC AR4, the change in the radiation budget due to anthropogenic aerosols, including the semi-direct and second indirect effects as well as the direct and first indirect effects, was estimated to be -0.3 to $-1.4 \mathrm{Wm}^{-2}$ as a "total aerosol effect". This is referred to as an adjusted forcing (AF), defined as a change in the net irradiance after allowing for atmospheric and land temperatures, water vapour, clouds, and land albedo to adjust to the prescribed sea surface temperatures and sea ice cover. The AF includes rapid responses of the climate system to the radiation budget. It is important to evaluate the AF because it helps clarify the integrated aerosol effects on climate change. It also generally provides a method for calculating the aerosol radiative effects in climate models.

Some previous studies have estimated historical time series for the RF of several climate forcing agents. Myhre et al. (2001) compiled a time series from the preindustrial era to 1995 using a radiative transfer model, and Hansen et al. (2002) estimated RF from 1950 to 2000 using a general cir- culation model from the Goddard Institute for Space studies (GISS). Takemura et al. (2006) calculated RF at both the tropopause and surface from 1850 to 2000 using an atmospheric general circulation model, MIROC, which applied the historical meteorological field simulated for the Coupled Model Intercomparison Project Phase 3 (CMIP3) (Nozawa et al., 2005). Recently Skeie et al. (2011) estimated the RF time series from the preindustrial era to the present day for well-mixed greenhouse gases, tropospheric and stratospheric ozone, and aerosols. They calculated the RF for aerosols using the historical emission inventories provided by Lamarque et al. (2010) and global aerosol distributions from an off-line chemical transport model, OlsoCTM2. On projecting future global aerosol distributions, Horowitz (2006) calculated them with the Special Report on Emissions Scenarios (SRES) which was used in the Third and Fourth Assessment Reports of IPCC. There are, however, no studies with the latest emission scenarios for estimating future aerosol radiative forcings.

In the present study, the time series of changes in the radiation budget due to aerosols from the preindustrial era to the present day and the present day to the end of the $21 \mathrm{st}$ century are estimated using an on-line global aerosol climate model, SPRINTARS (Takemura et al., 2000, 2002a, 2005, 2009), and using the Representative Concentration Pathways (RCPs) (Moss et al., 2010) for the latest future emission scenarios. The historical emissions database developed by Lamarque et al. (2010) and the RCPs for future emissions are used in the Coupled Model Intercomparison Project Phase 5 (CMIP5) in conjunction with the Fifth Assessment Report (AR5) of the IPCC. The simulation in this study is undertaken with a prescribed sea surface temperature and sea ice cover, so the estimated change in the radiation budget is the AF. Section 2 of this paper describes the model and the conditions used for the simulation. Section 3 describes the emission inventories for anthropogenic aerosols and the precursors and parameterisations of dust and sea salt emissions. Section 4 presents the changes in aerosol optical parameters as well as the atmospheric aerosol loadings and emissions of natural aerosols from the preindustrial era to the end of the 21 st century. Section 5 presents a time series of the AF resulting from the direct aerosol effect. Section 6 presents time series of some cloud parameters, including the AF resulting from the aerosol indirect effect. Finally, Sect. 7 presents the conclusions drawn from the study.

\section{Model description}

The SPRINTARS model calculates global distributions and climate effects of the main tropospheric aerosols, and is coupled with a general circulation model, MIROC5 (Watanabe et al., 2010). It was developed by the Division of Climate System Research in the Atmosphere and Ocean Research Institute (AORI) at the University of Tokyo, the National 


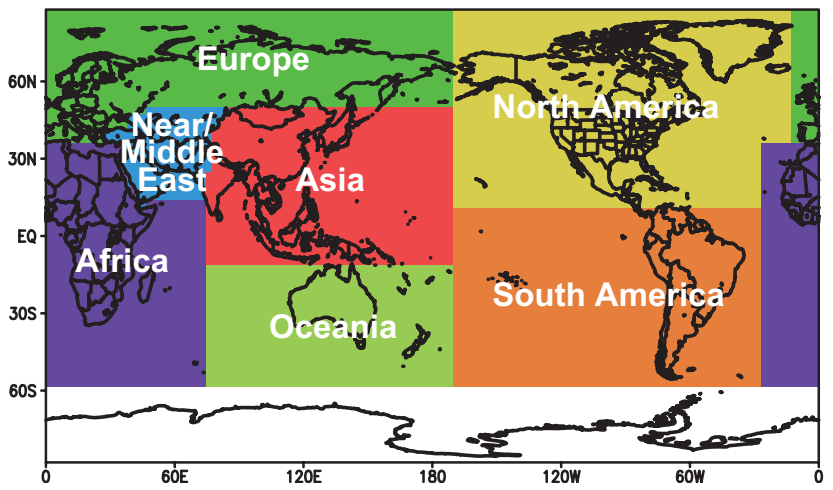

Fig. 1. Definition of regions in this study.

Institute for Environmental Studies in Japan (NIES), and the Research Institute for Global Change in the Japan Agency for Marine-Earth Science and Technology (JAMSTEC). The horizontal resolution used is T42 (approximately $2.8^{\circ}$ by $2.8^{\circ}$ in latitude and longitude) and the vertical resolution is 20 layers (sigma levels based on the surface pressure at $0.995,0.980,0.950,0.900,0.830,0.745,0.650,0.549,0.454$, $0.369,0.295,0.230,0.175,0.124,0.085,0.060,0.045,0.035$, 0.025 , and 0.008 ). The standard time step is $20 \mathrm{~min}$, but becomes shorter when the calculations are unstable. The data for the prescribed sea surface temperature and sea ice cover are obtained from historical and future climate simulations by MIROC and correspond to each emission scenario submitted to CMIP5. Figure 1 defines the regions used in this study.

The SPRINTARS model predicts the mass mixing ratios of black carbon (BC), particulate organic matter (POM), sulphate, soil dust, and sea salt, and the precursor gases of sulphate, i.e., sulphur dioxide $\left(\mathrm{SO}_{2}\right)$ and dimethyl sulphide (DMS). The aerosol transport processes include emission, advection, diffusion, sulphur chemistry, wet deposition, dry deposition, and gravitational settling. The aerosol emission data used in this study are explained in detail in the next section. The other aerosol transport processes are described in Takemura et al. (2000).

The direct, semi-direct, and indirect effects of aerosols are calculated in SPRINTARS, and are coupled with the radiation and cloud/precipitation processes of MIROC5. The twostream discrete ordinate and adding methods are adopted in the radiation scheme of MIROC5 (Sekiguchi and Nakajima, 2008) and consider refractive indices, size distributions, and hygroscopic growth for each aerosol component to calculate the aerosol direct effect. The wavelength-dependent refractive indices of dry aerosols and water are based on Deepak and Gerber (1983) and d'Almeida et al. (1991), respectively. This study does not include the deposition effects of radiative-absorbing aerosols (i.e., BC and soil dust particles) on the change of albedo for snow-covered surfaces. A detailed description of the aerosol direct effect in SPRINTARS is provided by Takemura et al. (2002a, 2005).

The aerosol indirect effect processes are also incorporated into a bulk microphysical scheme (Watanabe et al., 2010) for both water and ice clouds in SPRINTARS. The cloud droplet and ice crystal number concentrations, as well as liquid/ice water mixing ratio, are treated as prognostic variables (see Eqs. (C1) and (C2) in Takemura et al., 2009). The mass and number concentrations of cloud droplets and ice crystals vary due to the nucleation, accretion, riming, and aggregation processes. The nucleation of cloud droplets depends on the aerosol particle number concentrations, size distributions, curvature effect, and solute effect of each aerosol component based on a parameterisation in Abdul-Razzak and Ghan (2000). The cloud droplet effective radius and precipitation rate, which are related to the first and second indirect effects, respectively change according to the prognostic cloud droplet number concentration. A detailed description of the aerosol indirect effect for water clouds in SPRINTARS is provided by Takemura et al. (2005). For ice crystals, both homogeneous and heterogeneous nucleations are considered. The homogeneous process is based on Kärcher and Lohmann (2002), and the heterogeneous process, which includes contact and immersion/condensation freezings, is based on Lohmann and Diehl (2006) and Diehl et al. (2006). $\mathrm{BC}$ and soil dust particles are potential aerosol components, which can act as ice nuclei in the model. The parameterisation of interactions between aerosols and ice crystals are described in detail in Takemura et al. (2009).

This study includes the aerosol semi-direct effect process, because the radiation and cloud-precipitation processes interact in the model. The semi-direct effect due to $\mathrm{BC}$ in SPRINTARS is described in Takemura and Uchida (2011).

The past transient simulation from 1850 to 2005 and the future transient simulations with four RCPs from 2006 to 2100 are carried out in this study, which are the standard experiments (STD). The other experiments with continuous preindustrial emissions for aerosols and transient changes in other conditions along RCPs (AEROPI) are also done to analyse effects of changes in aerosol emissions on radiation and clouds by calculating differences with STD. The $\mathrm{AF}$ for the aerosol direct effect is calculated as a comparison of a difference in net radiation fluxes with and without aerosols by a double call of the radiation code between STD and AEROPI, i.e., ((STD with aerosols) - (STD without aerosols $))-(($ AEROPI with aerosols) - (AEROPI without aerosols)). It is under the all-sky condition in this study. The AF for the aerosol indirect effect is defined as a difference in the cloud radiative forcing between STD and AEROPI.

\section{Emissions and concentrations of aerosols}

The natural aerosols and their precursors included in this study are soil particles, sea salt, POM from the 

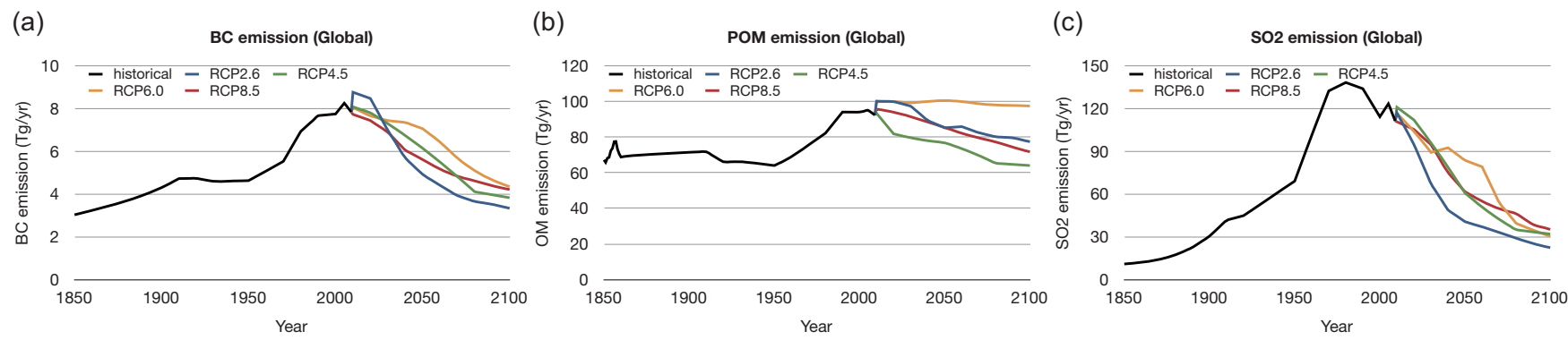

Fig. 2. Time series of annual and global total emissions of (a) BC, (b) POM, and (c) $\mathrm{SO}_{2}$ according to the RCPs. The historical period is shown in black, and the four RCPs are shown in colors.

gas-to-particle conversion of volatile organic compounds, volcanic $\mathrm{SO}_{2}$, and DMS from oceanic phytoplankton and land. The emission flux of soil dust aerosols depends on the near-surface wind speed, vegetation, leaf area index (LAI), soil moisture, and amount of snow (Takemura et al., 2009). Sea salt emissions depend on the near-surface wind speed, and emissions are not possible over areas covered by sea ice (Monahan et al., 1986; Takemura et al., 2009). For natural POM emissions, conversion rates from volatile organic compounds are assumed based on Griffin et al. (1999), and the emission inventories are those provided by Guenther et al. (1995). The Global Emissions Inventory Activity (GEIA) database is used to estimate $\mathrm{SO}_{2}$ emissions from continuously erupting volcanoes (Andres and Kasgnoc, 1998). DMS emissions depend on the downward surface solar radiation available for oceanic phytoplankton (Bates et al., 1987) and on the temperature and LAI as well as the downward surface solar radiation available for land vegetation (Spiro et al., 1992).

Historical and future emission inventories of annual mean anthropogenic sources and monthly mean biomass burning for $\mathrm{BC}$, organic carbon (OC), and $\mathrm{SO}_{2}$ are based on Lamarque et al. (2010) and RCPs (Moss et al., 2010), respectively. The RCPs have four representative pathways, each of which corresponds to a specific radiative forcing. RCP2.6 has a peak in the global mean $\mathrm{RF}$ at $2.6 \mathrm{~W} \mathrm{~m}^{-2}$ prior to 2100, and then RF declines. In RCP4.5 and RCP6.0, the global mean RF stabilises, without overshooting, to 4.5 and $6.0 \mathrm{~W} \mathrm{~m}^{-2}$, respectively after 2100 . In RCP8.5 the global mean $\mathrm{RF}$ reaches $8.5 \mathrm{~W} \mathrm{~m}^{-2}$ before 2100 and then continues to increase. Conversion factors from OC to POM are set at 1.6 and 2.6 for anthropogenic sources and biomass burning, respectively (Myhre et al., 2009). A time series of the monthly three-dimensional emission flux of BC from aviation sources is also included in the above database and is converted to POM and $\mathrm{SO}_{2}$ using factors of $1 / 3$ and $8.0 \times 10^{-4}$, respectively. Figure 2 presents a time series for total emissions of BC, $\mathrm{POM}$, and $\mathrm{SO}_{2}$ from 1850 to 2100 .

The monthly mean concentrations of hydroxyl radical $(\mathrm{OH})$, ozone $\left(\mathrm{O}_{3}\right)$, and hydrogen peroxide $\left(\mathrm{H}_{2} \mathrm{O}_{2}\right)$, all of which are oxidisers of DMS and $\mathrm{SO}_{2}$, were determined us- ing a global chemical climate model, CHASER (Sudo et al., 2002), which is driven by the same general circulation model, (MIROC) as the SPRINTARS model. In CHASER, values are calculated as time slices for every decade using the same emission inventories as those used in this study, and interpolated linearly for the intermediate years. Concentrations of long-lived greenhouse gases (carbon dioxide, methane, nitrous oxide, chlorofluorocarbons, etc.) are also determined according to the RCPs.

\section{Long-term trends of atmospheric aerosols}

Figure 3 presents the annual mean distributions of the mass column loading for each aerosol component in 2000. BC and POM are concentrated over Central and Southern Africa, the Amazon, and Southeast Asia, mainly due to emissions from biomass burning in the dry season of each region. Concentrations are also high over the populous and industrialised regions of East and South Asia, Europe, and North America, due to fossil and bio fuel consumption. Sulphate aerosols have high concentrations not only over East and South Asia, Europe, and North America, but also over the Arabian Peninsula due to oil production and surrounding volcanic regions. Unlike BC and POM, sulphate aerosol is also distributed over remote oceans, because of the emission of its precursor (DMS) from oceanic phytoplankton. Large amounts of soil aerosol appear over the Saharan, Arabian, Asian, and Australian regions. Sea salt aerosols have a more homogeneous distribution over oceans than other aerosols, although their concentration is high in the mid- and high-latitudes of both hemispheres due to the storm track.

The simulated aerosol distributions have been confirmed to generally agree with various aerosol observations by satellites and ground-based measurements, in terms of both climatology and short-term variations (Takemura et al., 2002b, 2003). They are also reasonably comparable with data from some satellite retrievals and ground-based observational networks for aerosols used in the aerosol model intercomparison project, AeroCom (Kinne et al., 2003; Textor et al., 2006). The AeroCom Phase II Interface, which provides comparisons of various aerosol parameters among models and 
(a)

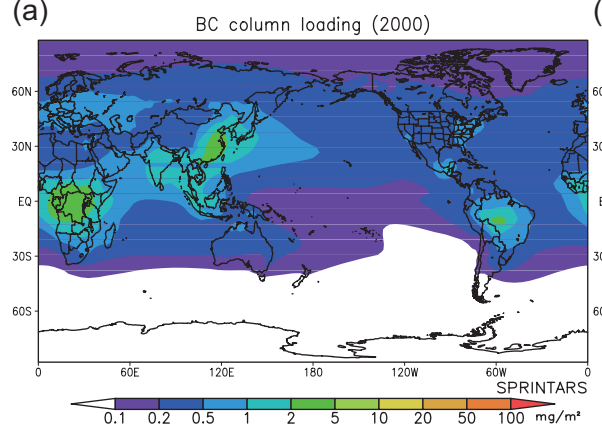

(d) (b)

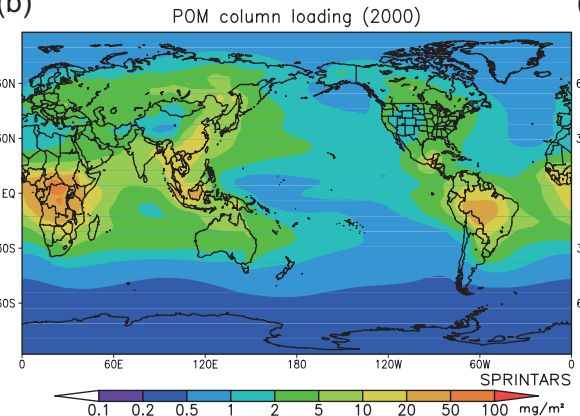

(c)

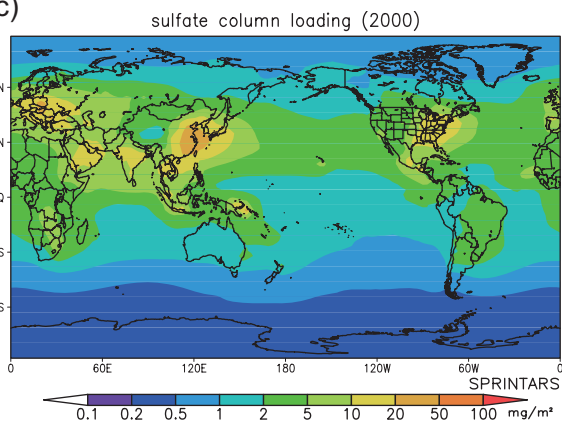

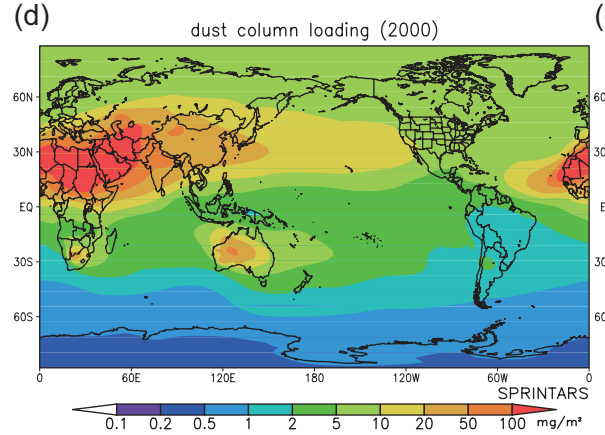

(e)

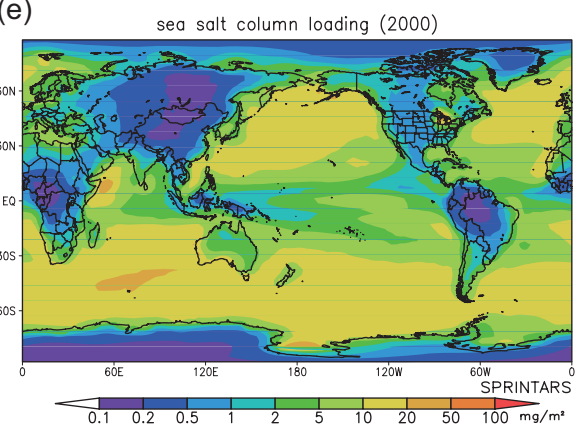

Fig. 3. Global distributions of mass column loadings of (a) BC, (b) POM, (c) sulphate, (d) soil dust, and (e) sea salt in 2000 (averaged over the period 1998-2002) simulated by SPRINTARS.

observations, is available at http://aerocom.met.no/cgi-bin/ AEROCOM/aerocom/surfobs_annualrs.pl.

Figure 4 presents the simulated time evolution of annual mean mass column loadings for BC, POM, and sulphate from 1850 to 2100 dividing into several regions. The values in the hindcast simulation from 1850 to 2005 are the same for all scenarios in each component. All components have already decreased in Europe and North America, particularly sulphate, and they are predicted to continue decreasing toward the end of the 21 st century. In contrast, the mass column loadings in Asia have not yet reached their maximum values for all components, with the exception of POM with RCP4.5. This is mainly because anthropogenic aerosol emissions are estimated to continue increasing until at least 2030 due to rapid economic growth in some countries. In RCP6.0, all aerosol components maintain high loadings until the mid21st century in Asia, although they are predicted to decrease by the end of the century for all RCPs. Biomass burning in Africa is predicted to ensure a high aerosol mass loading throughout the 21st century in all RCPs, particularly for $\mathrm{BC}$ and $\mathrm{POM}$, although it is difficult to provide a quantitative estimate of future emissions from biomass burning. The $\mathrm{BC}$ and POM loadings from Africa are approximately half of the global total in the latter half of the 21st century. Sulphate aerosols originating from the Near and Middle East began to increase from the end of the 20th century, mainly because of oil production and economic growth, and this situation continues toward the mid-21st century, with the exception of RCP2.6. Horowitz (2006) using the SRES estimated that atmospheric $\mathrm{BC}$ and $\mathrm{OC}$ monotonically increase toward the end of the 21st century except in the scenario which has the smallest emission amounts (SRES B1) although burdens of sulfate aerosols have peaks in the mid-21st century in all scenarios. The future projections of atmospheric burdens and consequent radiative forcings and climate effects of aerosols are greatly different between applied emission scenarios.

Aerosol emissions from natural sources can change due to climate change. Figure 5 presents the long-term trends of major natural aerosol emissions (soil dust particles and sea salt). The largest emission sources of soil dust are the Saharan and Arabian regions (Fig. 5b), where the arid area is predicted to expand due to global warming (Fig. 5c). This is the reason for the increasing trend of total global soil dust particle emissions in the 21 st century, particularly for RCP8.5, where the increase in carbon dioxide concentration is highest (Fig. 5a). By the end of the 21st century, the emission of soil dust particles is estimated to be approximately $40 \%$ greater in RCP8.5 and $20 \%$ greater in both RCP6.0 and RCP4.5 than current emissions. The total global sea salt emission is also predicted to increase during the 21 st century, mainly because of melting sea ice in the Arctic due to global warming, consequently exposing the sea surface to the atmosphere (Fig. 5e, f). Sea salt emissions will increase by $1-2 \%$ by the end of this century, relative to the present day (Fig. 5d). Note that these changes in natural aerosol emissions can be negligible for estimates of adjusted forcing (AF) provided in the following sections, because the $\mathrm{AF}$ is calculated as the difference in the radiation budget from the experiment using emission 
(a)

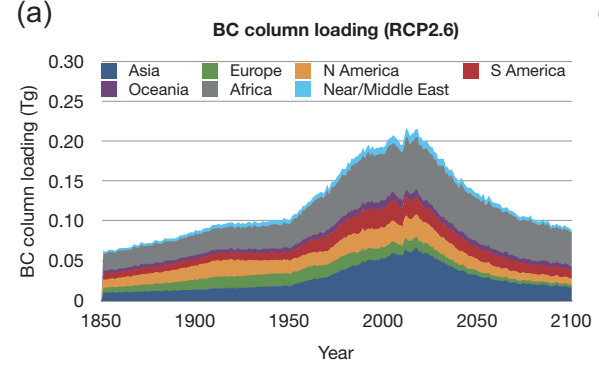

(d)

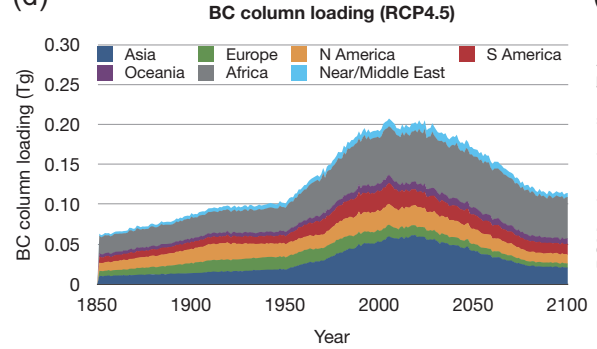

(g)

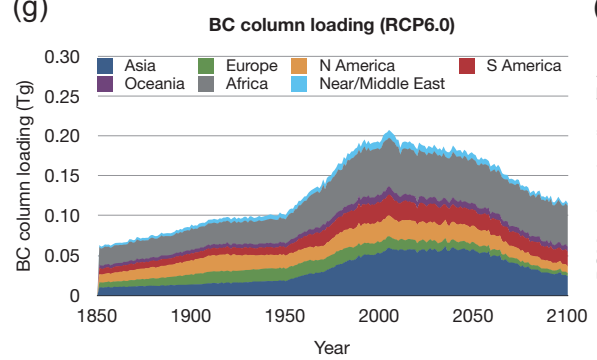

(j)

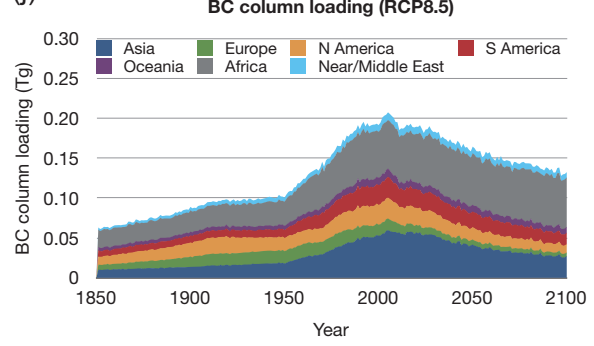

(b)

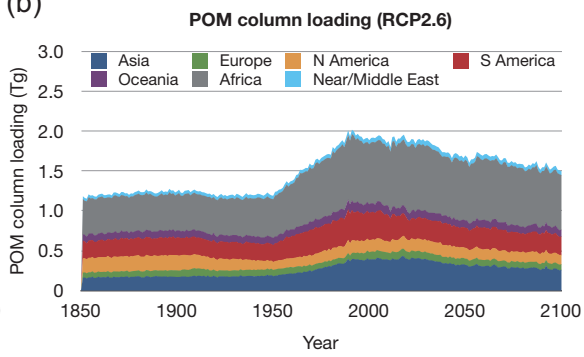

(e)

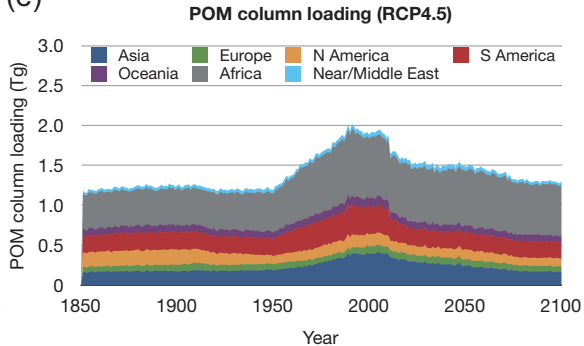

(h)

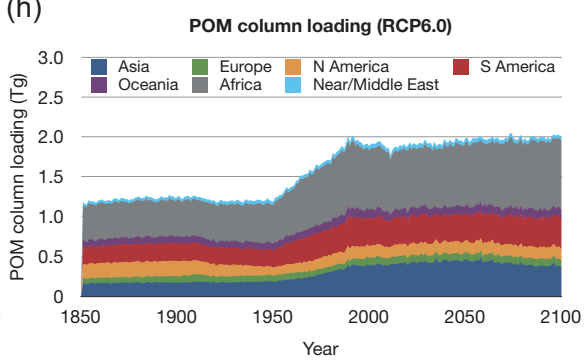

(k)

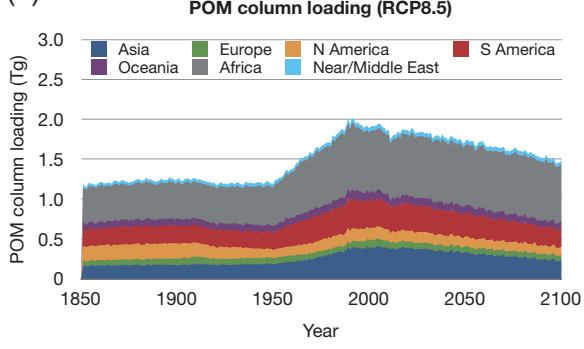

(c) sulfate column loading (RCP2.6)

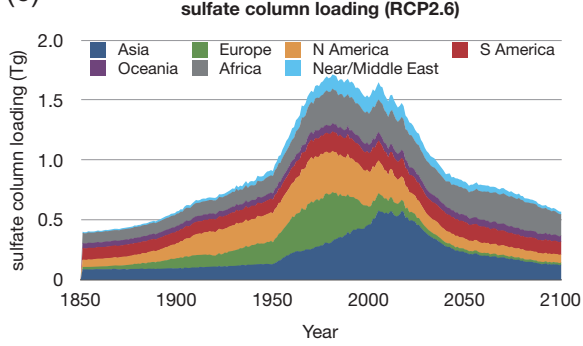

(f)

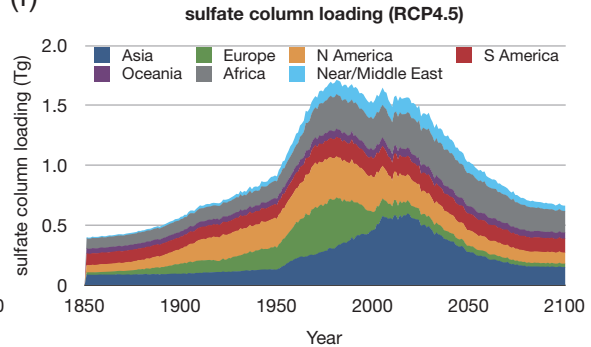

(i)

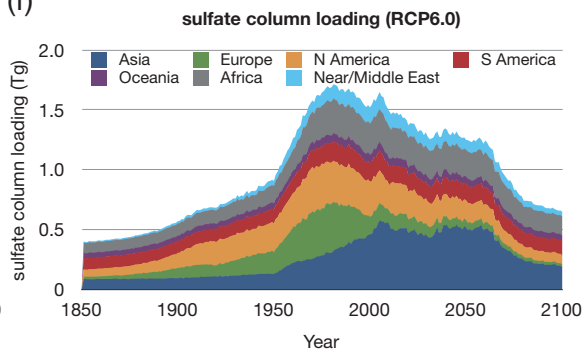

(I)

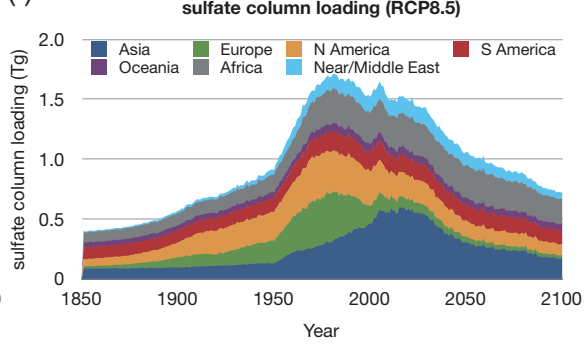

Fig. 4. Time series of regional total mass column loadings of (left) BC, (middle) POM, and (right) sulphate for (top to bottom) RCP2.6, 4.5, 6.0, and 8.5 simulated by SPRINTARS. Blue: Asia, green: Europe, orange: North America, red: South America, purple: Oceania, grey: Africa, light blue: Near and Middle East.

inventories of anthropogenic aerosols for 1850 with the same sea surface temperature, sea ice cover, and concentrations of greenhouse gases data as the standard transient experiment.

Figure 6 presents a time series of aerosol optical thickness (AOT) and single scatting albedo (SSA) simulated by SPRINTARS. The global mean AOT rapidly increases after the 1950s and reached a maximum in the 1970s to 1990s (Fig. 6a). From this point it gradually decreases toward the end of the 21 st century in the simulations for all RCPs, although the decrease temporally ceases in the mid-21st century in RCP6.0. The minimum SSA is delayed in comparison with the maximum AOT because the reduction of $\mathrm{SO}_{2}$ emission precedes that of $\mathrm{BC}$, due to the adoption of inexpen- sive desulphurisers and because $\mathrm{BC}$ emissions from biomass burning regions remain high (see Figs. 2 and 4). The regional AOT in Europe and North America (Fig. 6c, d) peaks in the 1970s to 1980s, which is synchronised with the global mean. The SSA decreases until early this century in RCP4.5 for North America and in RCP2.6 for both North America and Europe, due to the rapid reduction of $\mathrm{SO}_{2}$ emissions, before it later recoveres. In Asia, the AOT increases after the Second World War and reaches a maximum in the 2010s, with the exception of RCP6.0, where anthropogenic aerosols remain at high levels until the mid-21st century (Fig. 4). Although emissions of anthropogenic aerosols are declining in Japan, as in Europe, those in other Asian countries are increasing. 
(a)

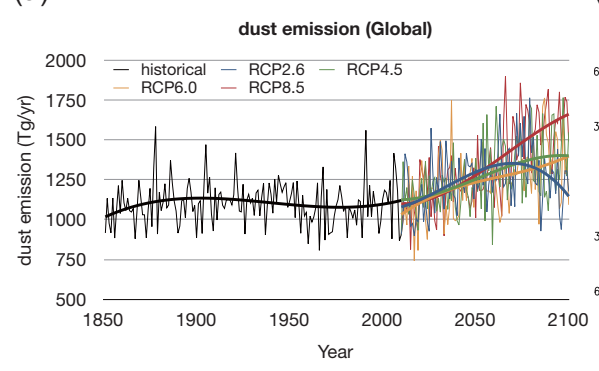

(d)

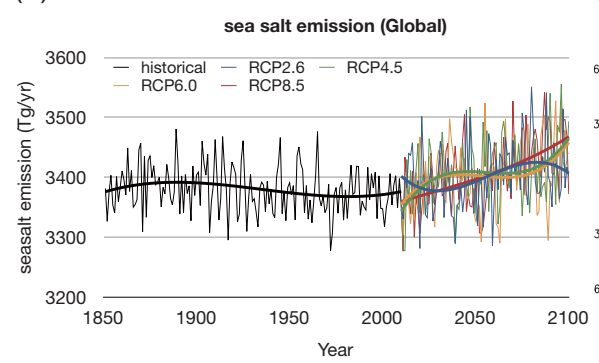

(b)

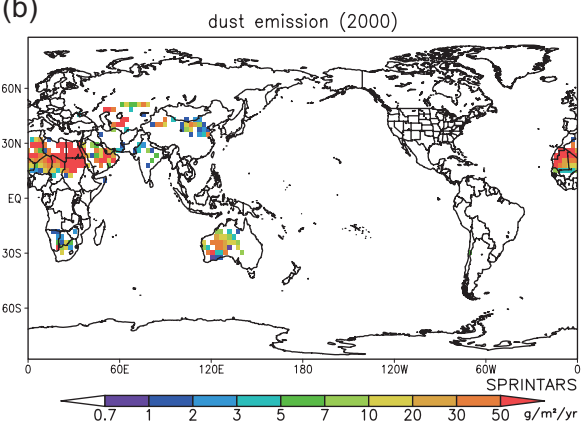

(e)

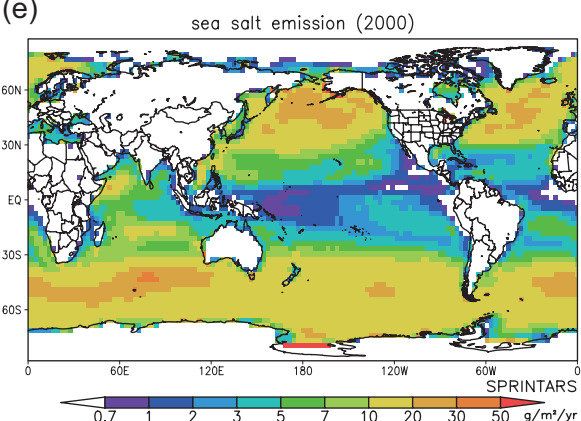

(c)

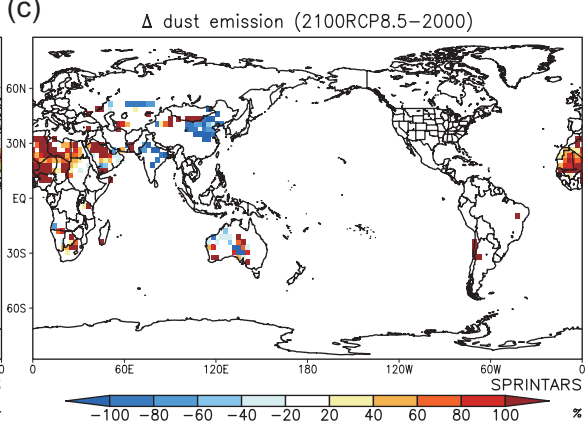

(f)

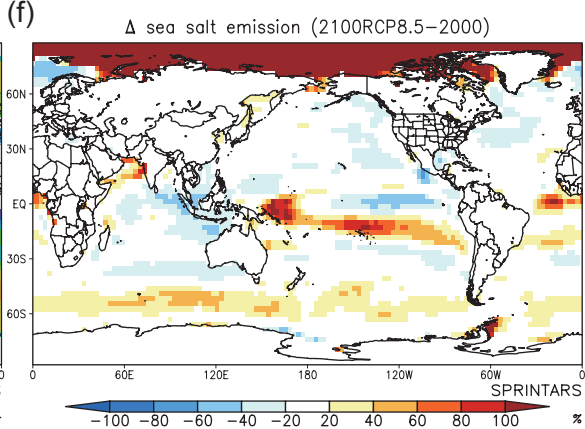

Fig. 5. Time series of annual and global total emissions of (a) soil dust and (d) sea salt, and global distributions of emissions of (b) soil dust and (e) sea salt in 2000 (averaged over the period 1998-2002) and their ratio in 2100 (averaged over the period 2096-2100) for the RCP8.5 experiment against 2000 of (c) soil dust and (f) sea salt simulated by SPRINTARS. In (a) and (d), historical period is shown in black, the four RCPs are shown in colours, and the thick lines are regression curves.

The SSA is lower in Asia than in Europe and North America, and its uncertain future trend depends on the RCP selected. The AOT in South America peaks in the 1990s and then decreases according to the RCPs (Fig. 6e), but recent studies have predicted an increase in emissions from fires by the end of the 21st century relative to the present day (Pechony and Shindell, 2010; Kloster et al., 2012). This makes it difficult to estimate future emission trends biomass burning. The AOT in Africa during this century is predicted to change less than in other regions due to biomass burning, as shown in Fig. 4.

\section{Time evolution of changes in the radiation budget due to the aerosol direct effect}

The time evolution of changes in radiation budget by the aerosol direct effect is expected to depend on the aerosol optical thickness (AOT) and single scattering albedo (SSA), shown in Fig. 6. Figures 7 and 8 present a time series and global distribution of the adjusted forcing (AF) from the aerosol direct effect at the tropopause, respectively. The global mean AF at the tropopause due to the aerosol direct effect is negative after the 1950 s and reaches a maximum in the 1970 s to 1990 s of over $-0.2 \mathrm{Wm}^{-2}$ (Fig. 7a), which is a similar temporal variation to the AOT. It seems that its recovery phase toward the neutral value has already begun although the recovery paths depend on the RCP selected. In RCP4.5, recovery is steady throughout this century, while re- covery is stagnant in the middle of this century in RCP2.6. In RCP8.5, the AF will reach zero by the end of this century, despite a delay in the onset of the recovery for a few decades from the present day. The AF recovers the slowest in RCP6.0. Table 1 lists the global mean AF for each RCP, for every decade. In Asia, the regional mean AF over land is more than $-1.0 \mathrm{~W} \mathrm{~m}^{-2}$ for the present day, and the trends in each RCP for this century are similar to those of the global means (Fig. 7b). One of the main reasons for RCP6.0 having the slowest recovery on the global mean is the Asian region. The AF due to the aerosol direct effect in Europe and North America reaches a maximum in the 1970s to 1990 s, which is consistent with the trend of AOT, and little difference is predicted in the future trends among all RCPs, although the recovery in RCP2.6 is predicted to be rapid before the 2030s in Europe (Fig. 7c, d). The AF is predicted to recover to close to its preindustrial level by the mid-21st century in Europe and North America. The AF relative to the preindustrial era remains positive after the middle of the century in North America (Figs. 7d and 8), because emissions from fossil fuel consumption had already commenced prior to 1850 and because the future reduction of $\mathrm{BC}$ is slower than that of sulphate. In South America, the future trends of each RCP are similar to those in Asia, which indicates a late recovery from the negative AF in RCP6.0, while they are close to zero until the end of this century in the other RCPs (Fig. 7e). As well as fossil fuel consumption, the primary source of anthropogenic 

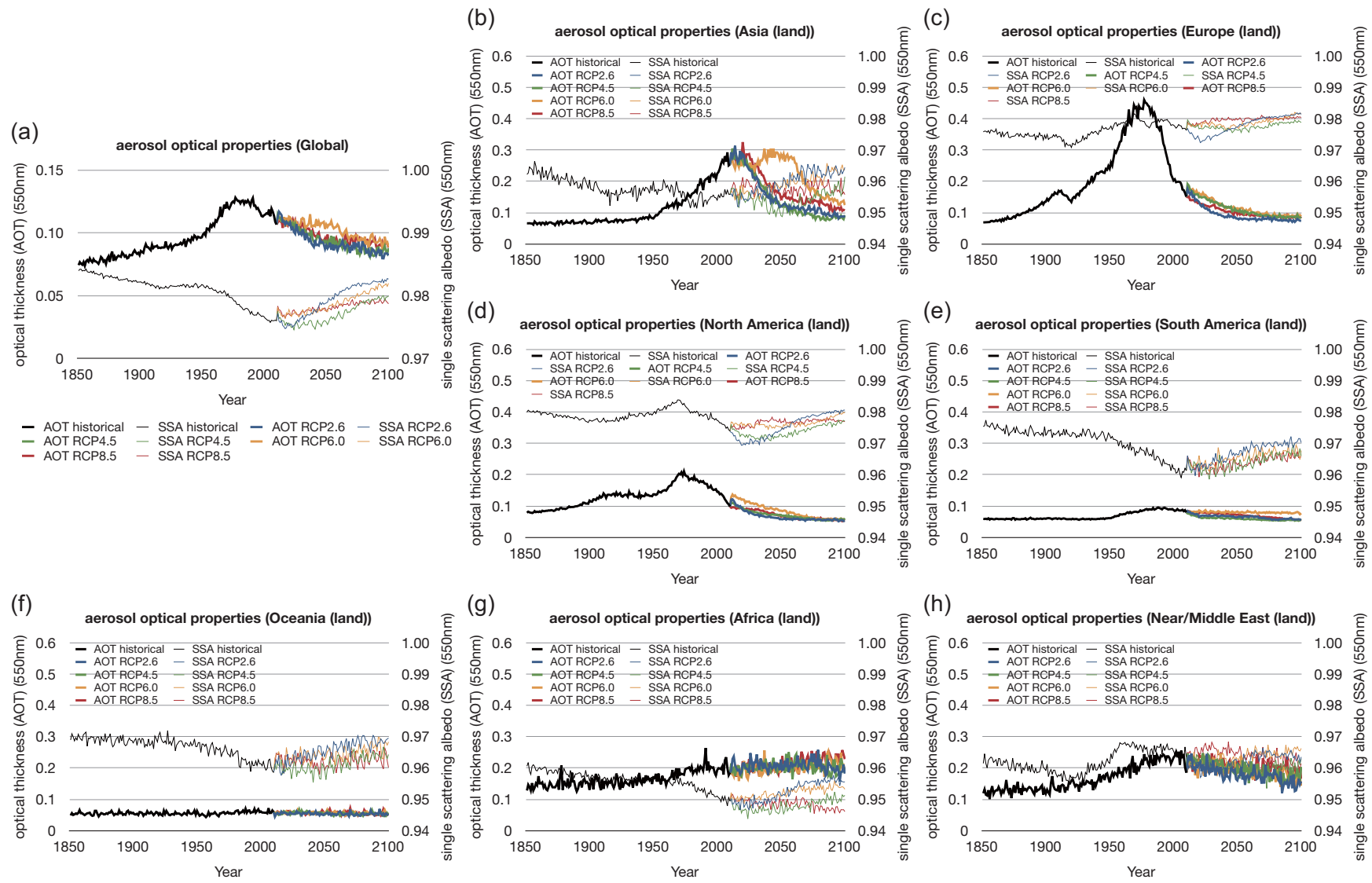

Fig. 6. Time series of annual and (a) global or (b)-(h) regional mean optical thickness (thick lines) and single scattering albedo (thin lines) simulated by SPRINTARS. The regional mean values are only over land. The historical period is shown in black, and the four RCPs are shown in colors.

aerosols in South America is biomass burning, which mainly releases $\mathrm{BC}$ and $\mathrm{POM}$, hence the AF due to the aerosol direct effect at the tropopause can become positive. Figure 4 shows that in Africa, the future aerosol emissions in this century in all RCPs will keep high relative to present-day levels, so the $\mathrm{AF}$ will retain large negative values (Fig. $7 \mathrm{~g}$ ). The AF trend for the Near and Middle East corresponds to a change in sulphate loading, as shown in Fig. 4.

The forcing at the surface is also important to clarify changes in the atmospheric radiation budget and in the meteorological conditions near the surface. For example, $\mathrm{BC}$ has a positive forcing at the tropopause and the top of the atmosphere, while it has a negative forcing at the surface. This implies that $\mathrm{BC}$ absorbs solar and thermal radiation in the atmosphere. Takemura et al. (2006) reported that the total surface negative forcing due to major climate forcing agents rapidly increased after 1955, mainly due to the strong negative forcing of the aerosol direct effect. Figure 9 presents a time series of the AF at the surface from 1850 to 2100 , and Fig. 10 presents the global distribution. The trend of the global mean AF at the surface (Fig. 9a) is similar to that at the tropopause (Fig. 7), while the maximum value at the sur- face $\left(-1.0 \mathrm{~W} \mathrm{~m}^{-2}\right)$ is much larger than that at the tropopause. The AF at the surface in 2000 is negative virtually all over the globe (Fig. 10a). The difference in the AF between the tropopause and the surface is due to aerosols absorbing solar and thermal radiation, which is enhanced by the absorption of multi-scattered radiation in the cloud layers below the aerosols (Haywood and Ramaswamy, 1998; Takemura et al., 2002a). In Asia, the maximum negative AF is more than $-5 \mathrm{Wm}^{-2}$ for the present day (Fig. 10), and the recovery is delayed in RCP6.0, as well as at the tropopause (Fig. 9b). In North America, the AF at the surface is predicted to shift to a positive value after the 2020s (Figs. 9d and 10), which is consistent with the values shown in Fig. 7d. This is primarily because the aerosol emissions from Eastern North America after the 2020s are almost equal to or less than those in 1850 in all RCPs. In Africa, the AF at the surface is not expected to recover during the 21 st century (Fig. 9g). The high BC concentration is maintained throughout this century (Fig. 4), and is emitted to high altitudes due to the heat of the fires from which it originates. This enhances the absorption of the multi-scattered radiation by cloud layers, as described above. 
(a) direct adjusted forcing (Global; tropopause)
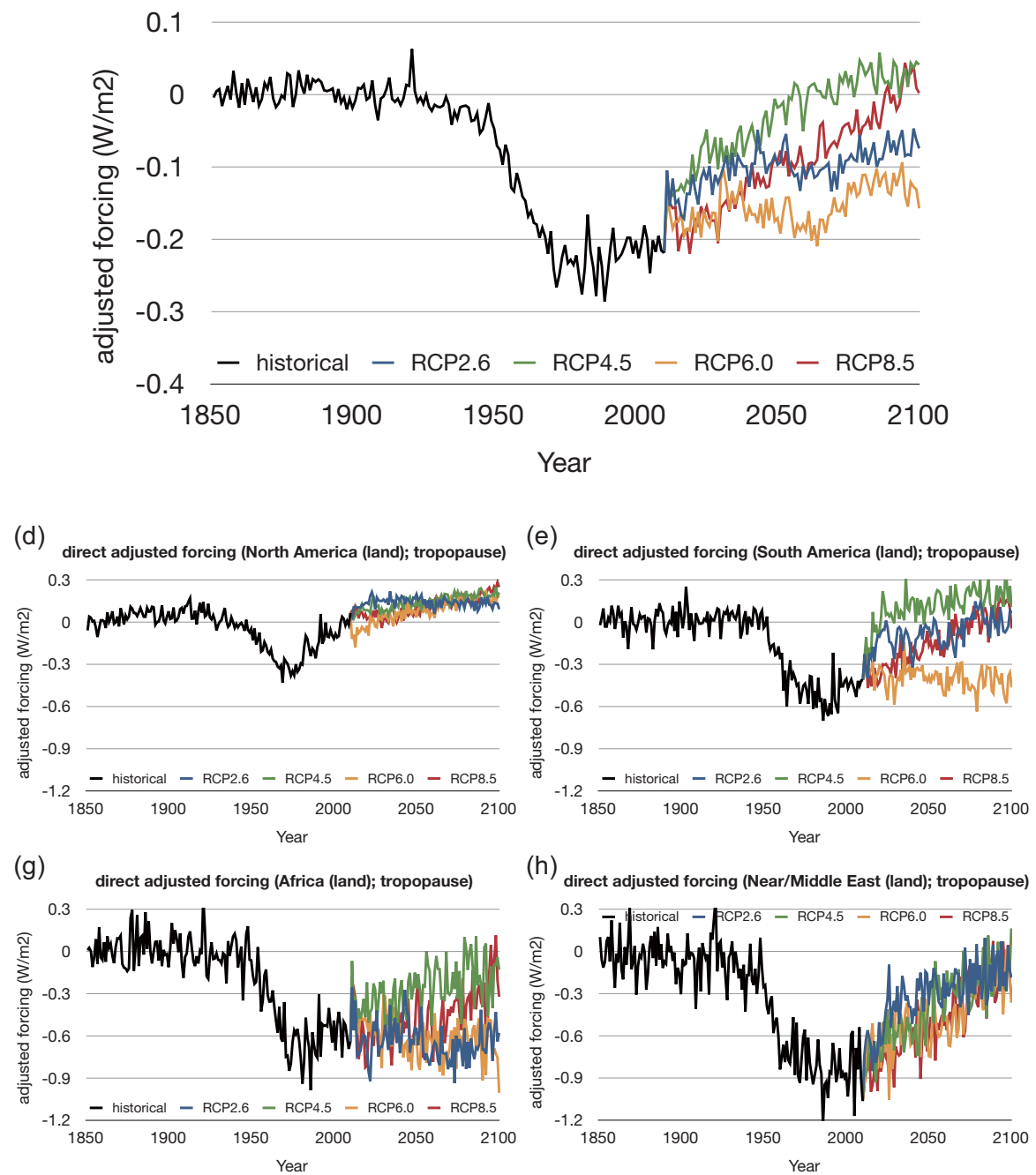

(h)

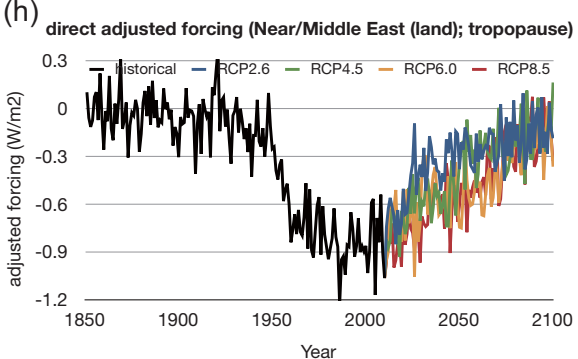

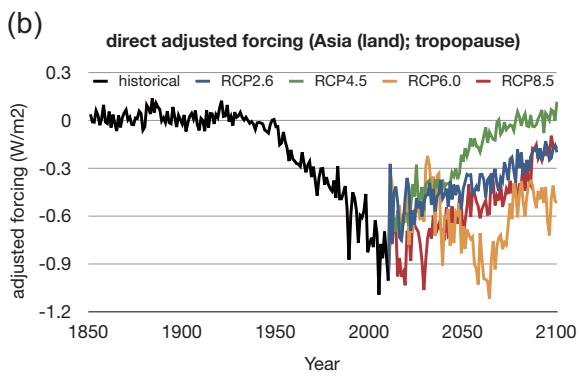

(c)
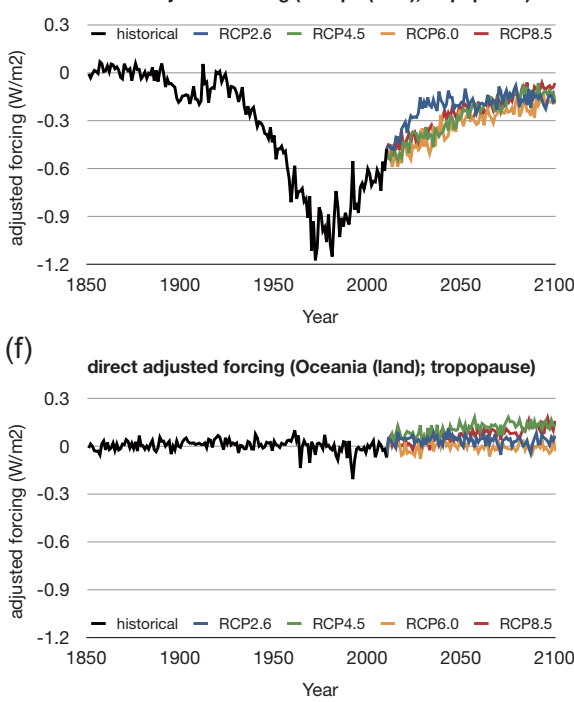<smiles>CCC</smiles>

Fig. 7. Time series of annual and (a) global or (b)-(h) regional mean adjusted forcing due to the aerosol direct effect at the tropopause relative to the preindustrial experiment simulated by SPRINTARS. The regional mean values are only over land. The historical period is shown in black, and the four RCPs are shown in colours.

Figure 11 presents the global mean AF due to the aerosol direct effect for each aerosol component until 2010, both at the tropopause and the surface. These separations are expedient because many aerosol components interact each other in the real atmosphere. The components that have the largest negative and positive $\mathrm{AF}$ at the tropopause are sulphate and BC from fossil fuel consumption, respectively. POM from fossil fuel is also an important forcing agent, generating a negative forcing at the tropopause mainly in the Asian region (not shown). The AF from biomass burning includes both $\mathrm{BC}$ and POM components, so the respective positive and negative forcing cancel each other out. The contribution towards the negative $\mathrm{AF}$ at the surface is estimated to be almost equal among sulphate and $\mathrm{BC}$ from fossil fuel consumption and aerosols from biomass burning.

\section{Time evolution of changes in the cloud parameters and radiation budget due to the aerosol indirect effect}

As described in Sect. 2, MIROC5-SPRINTARS includes parameterisations of the aerosol indirect effect both for cloud droplets and ice crystals, which are treated as two-moment schemes by predicting their mass mixing ratio and number concentration. A sensitivity of a change in the cloud droplet number concentration which is a basic parameter to estimate its radius to a change in AOT in the SPRINTARS are close to 
(a)

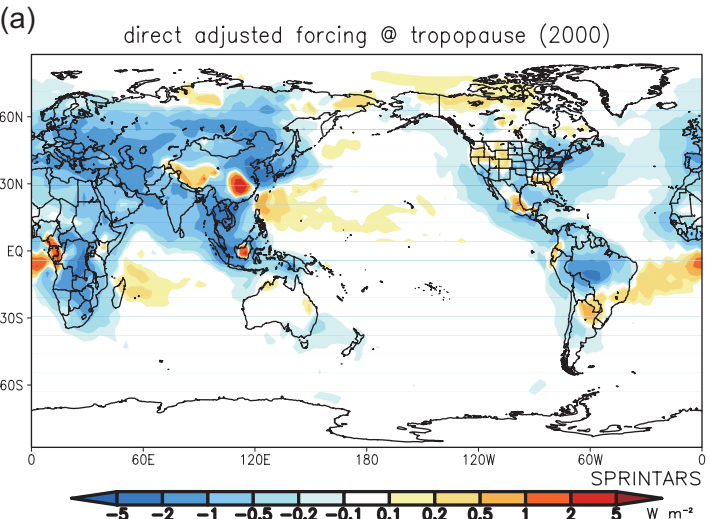

(b)

(b) direct adjusted forcing @ tropopause (2050 RCP2.6)

(C) direct adjusted forcing @ tropopause (2050 RCP4.5)
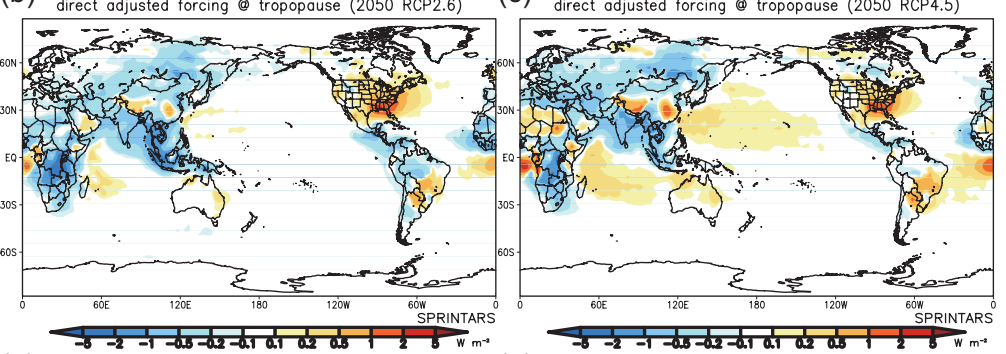

(d)

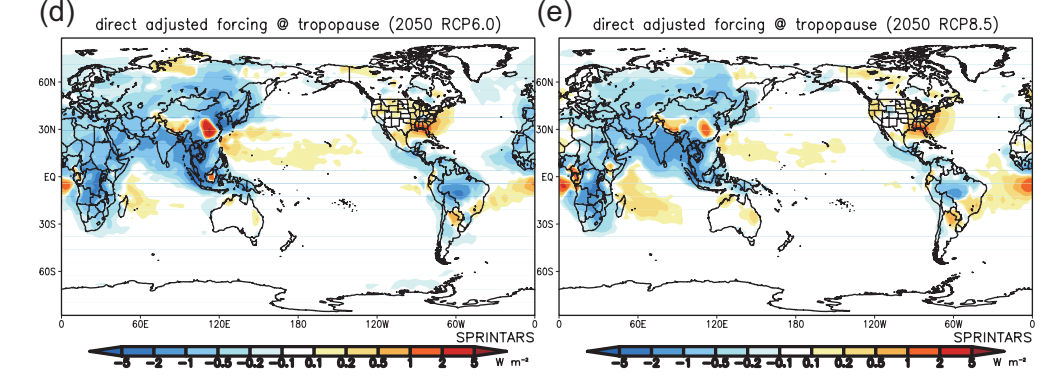

(e) direct odjusted forcing $\bullet$ tropopouse (2050 RCP.5)

Fig. 8. Global distributions of adjusted forcing due to the aerosol direct effect at the tropopause in (a) 2000 (averaged over the period 1998-2002) and (b)-(e) 2050 (averaged over the period 2048-2052) for the four RCPs relative to the preindustrial experiment simulated by SPRINTARS.

Table 1. Global mean adjusted forcing (in $\mathrm{W} \mathrm{m}^{-2}$ ) due to the aerosol direct effect at the tropopause and surface in each decade $(5$-yr running mean) relative to the preindustrial experiment simulated by SPRINTARS.

\begin{tabular}{|c|c|c|c|c|c|c|c|c|c|c|}
\hline & \multicolumn{5}{|c|}{ Tropopause } & \multicolumn{5}{|c|}{ Surface } \\
\hline & Hindcast & RCP2.6 & RCP4.5 & RCP6.0 & RCP8.5 & Hindcast & RCP2.6 & RCP4.5 & RCP6.0 & RCP8.5 \\
\hline 1860 & +0.00 & & & & & -0.02 & & & & \\
\hline 1870 & +0.01 & & & & & -0.06 & & & & \\
\hline 1880 & +0.01 & & & & & -0.06 & & & & \\
\hline 1890 & +0.01 & & & & & -0.07 & & & & \\
\hline 1900 & -0.01 & & & & & -0.10 & & & & \\
\hline 1910 & -0.01 & & & & & -0.14 & & & & \\
\hline 1920 & +0.02 & & & & & -0.17 & & & & \\
\hline 1930 & -0.02 & & & & & -0.18 & & & & \\
\hline 1940 & -0.02 & & & & & -0.20 & & & & \\
\hline 1950 & -0.05 & & & & & -0.24 & & & & \\
\hline 1960 & -0.14 & & & & & -0.42 & & & & \\
\hline 1970 & -0.22 & & & & & -0.60 & & & & \\
\hline 1980 & -0.25 & & & & & -0.78 & & & & \\
\hline 1990 & -0.23 & & & & & -0.96 & & & & \\
\hline 2000 & -0.21 & & & & & -0.95 & & & & \\
\hline 2010 & & -0.18 & -0.18 & -0.19 & -0.19 & & -0.98 & -0.92 & -0.93 & -0.91 \\
\hline 2020 & & -0.13 & -0.11 & -0.18 & -0.19 & & -0.91 & -0.82 & -0.87 & -0.91 \\
\hline 2030 & & -0.11 & -0.08 & -0.14 & -0.17 & & -0.79 & -0.78 & -0.88 & -0.84 \\
\hline 2040 & & -0.10 & -0.06 & -0.16 & -0.12 & & -0.59 & -0.68 & -0.85 & -0.74 \\
\hline 2050 & & -0.09 & -0.02 & -0.17 & -0.09 & & -0.49 & -0.61 & -0.80 & -0.66 \\
\hline 2060 & & -0.11 & -0.01 & -0.18 & -0.10 & & -0.48 & -0.51 & -0.79 & -0.59 \\
\hline 2070 & & -0.11 & +0.00 & -0.16 & -0.07 & & -0.40 & -0.40 & -0.66 & -0.52 \\
\hline 2080 & & -0.08 & +0.03 & -0.13 & -0.04 & & -0.33 & -0.30 & -0.61 & -0.50 \\
\hline 2090 & & -0.07 & +0.02 & -0.12 & -0.00 & & -0.28 & -0.26 & -0.54 & -0.41 \\
\hline 2100 & & -0.07 & +0.03 & -0.14 & +0.02 & & -0.25 & -0.23 & -0.53 & -0.37 \\
\hline
\end{tabular}


(a) direct adjusted forcing (Global; surface)
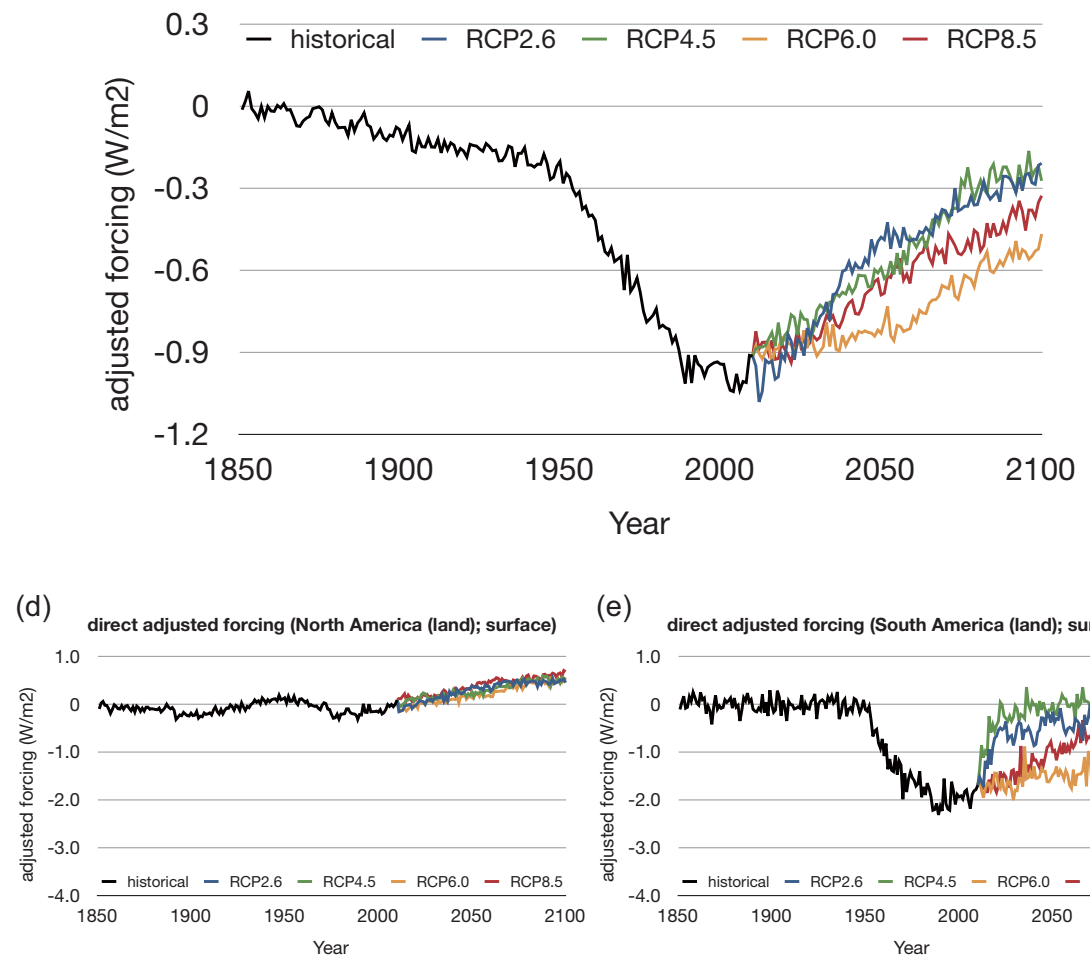

(g)

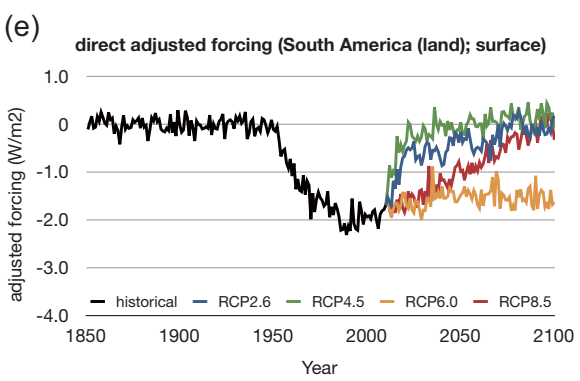

(h)

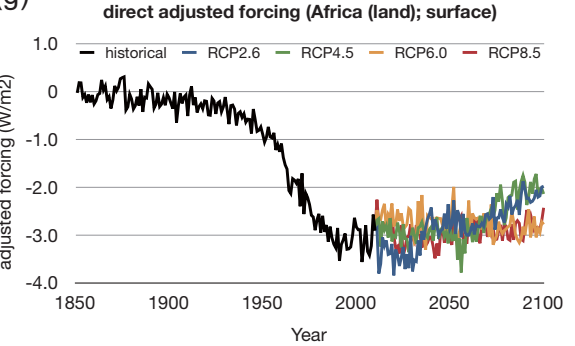

direct adjusted forcing (Near/Middle East (land); surface)

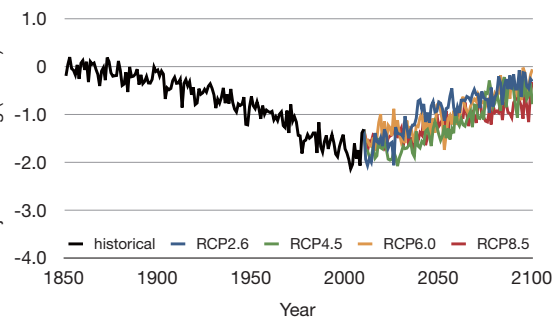

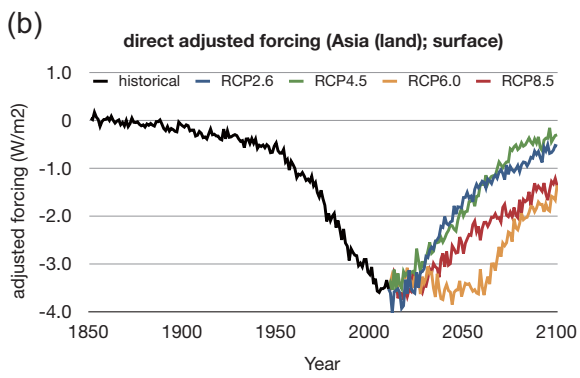

(c)
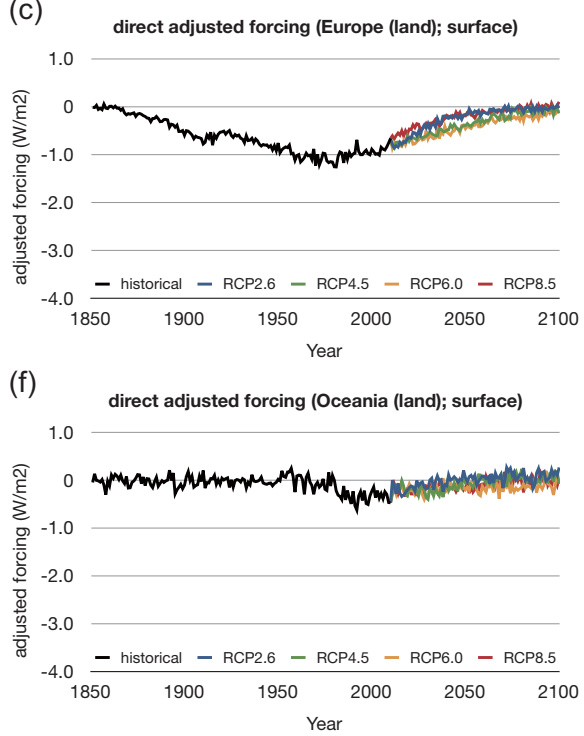

Fig. 9. Time series of annual and (a) global or (b)-(h) regional mean adjusted forcing due to the aerosol direct effect at the surface relative to the preindustrial experiment simulated by SPRINTARS. The regional mean values are only over land. The historical period is shown in black, and the four RCPs are shown in colours.

that from the satellite retrieval (Quaas et al., 2009). Figure 12 presents changes in the effective radii of cloud droplets and ice crystals at the cloud top. The cloud droplets are smaller in the present day than in the preindustrial era almost all over the globe, particularly the high aerosol concentration regions in the Northern Hemisphere (Fig. 12b, c). The maximum global mean change relative to the preindustrial era is $-0.8 \mu \mathrm{m}$ around 1990 (Fig. 12a). The ratio of the change is $-7 \%$, which is close to the value reported in a previous study (Takemura et al., 2005). Few differences are estimated in the cloud droplet effective radius in the different RCPs for the future projection, although it is slightly smaller in RCP6.0 in the mid-21st century, which is consistent with the change in aerosol loading (Figs. 4 and 6). The size of present-day ice crystals at the cloud top is estimated to be smaller than in preindustrial era over mid- and high-latitudes of the Northern Hemisphere, whereas it is larger over the tropics (Fig. 12e, f). Small ice crystals are mainly the result of an increase in BC concentration (Lohmann, 2001). The number concentration of ice crystals produced via homogeneous nucleation by which tropical cirrus clouds are mainly formed decreases due to an increase in the temperature in this study using a parameterization of Kärcher and Lohmann (2002), so that the size of each ice crystal increases in the tropics. The global mean change reaches a maximum around 1990, and the ratio of this change is estimated to be $-4 \%$. 
(a)

direct adjusted forcing @ surface (2000)

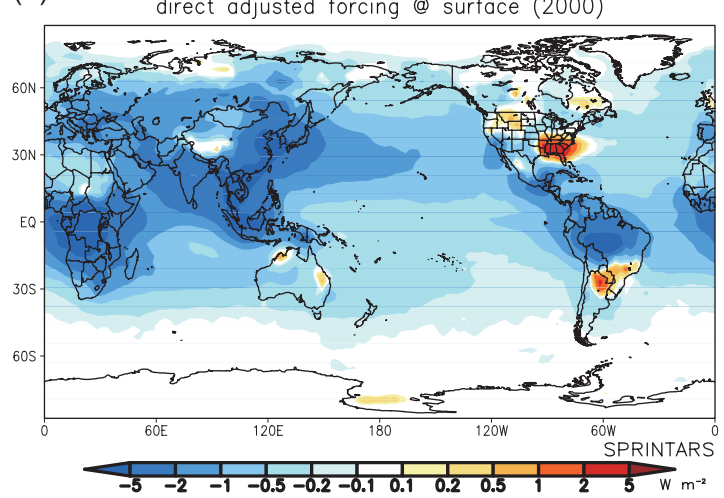

(b)

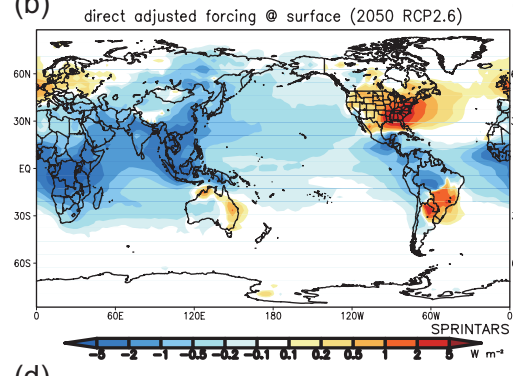

(d)

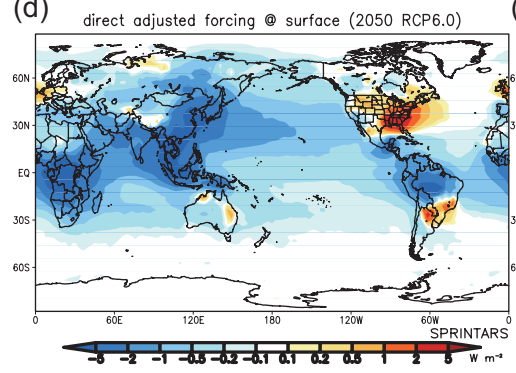

(c)

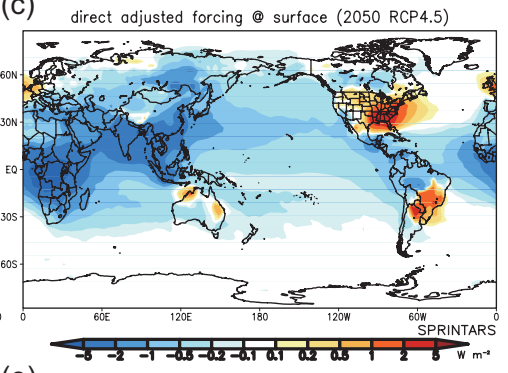

(e)

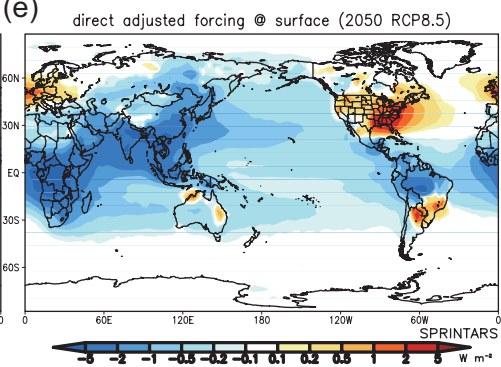

Fig. 10. Global distributions of adjusted forcing due to the aerosol direct effect at the surface in (a) 2000 (averaged over the period 1998-2002) and (b)-(e) 2050 (averaged over the period 2048-2052) for the four RCPs relative to the preindustrial experiment simulated by SPRINTARS.

(a)

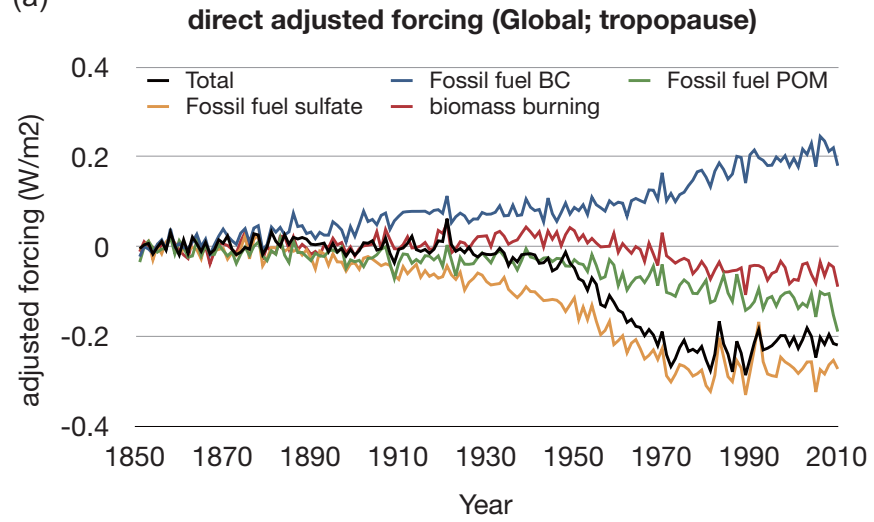

(b)

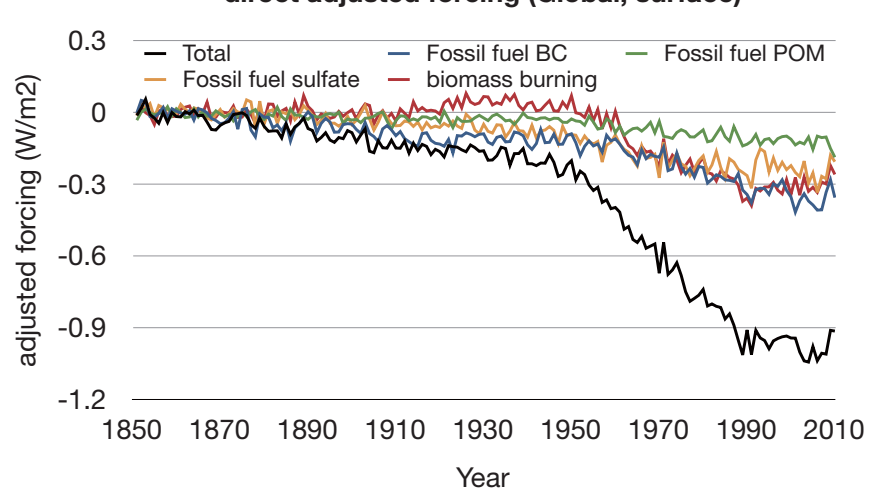

Fig. 11. Time series of annual and global mean adjusted forcing due to the direct effect by aerosols from fossil fuel (BC, POM, and sulphate) and from biomass burning at the (a) tropopause and (b) surface relative to the preindustrial experiment simulated by SPRINTARS.

A trend for the liquid water path to increase from the preindustrial era to the present day is prominent over Europe, East Asia, and North America, where aerosol concentrations are high (Fig. 13b). In the other regions, however, this trend is not obvious, because an analysis of changes in parameters between the years concerned and the preindustrial era includes a rapid response of the climate system to the aerosol effects, which may not result in simple trends in areas where aerosol concentrations are not high. In the mid-21st century, the increasing trend of the liquid water path is predicted to be less distinct than for the present day, although it is still larger than in the preindustrial era in Eurasia and East Asia and less than parts of North America (Fig. 13c), which corresponds to the variations of AOT (Fig. 6). Changes in the liquid water path with changes in AOT are quantitatively similar to satel- lite retrievals in SPRINTARS (Quaas et al., 2009). The ice water path is estimated to increase slightly from the preindustrial era to the present day and to decrease in the future, although the spatial pattern is not clear (Fig. 13d-f). Few differences are estimated in the liquid and ice water paths in the different RCPs for the future projection.

Based on the above analyses of changes in the aerosol loading, and the size and water path of cloud droplets and ice crystals, forcing by the indirect aerosol effect can be considered. Figures 14 and 15 present a time series and global distribution of the adjusted forcing (AF) due to the aerosol indirect effect at the tropopause, respectively. The global and regional trends are generally similar to those of the aerosol direct effect (Fig. 7). The year-to-year variations are, however, much larger than the variations due to the direct effect 
(a)

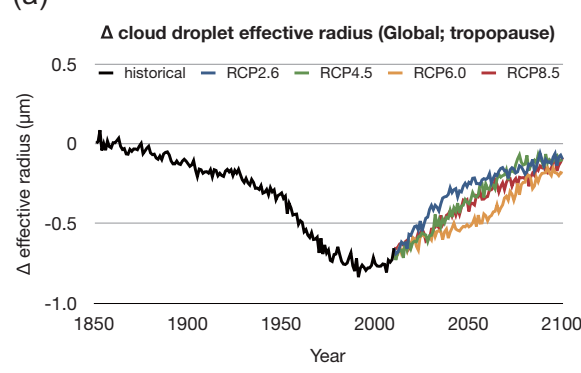

(d)

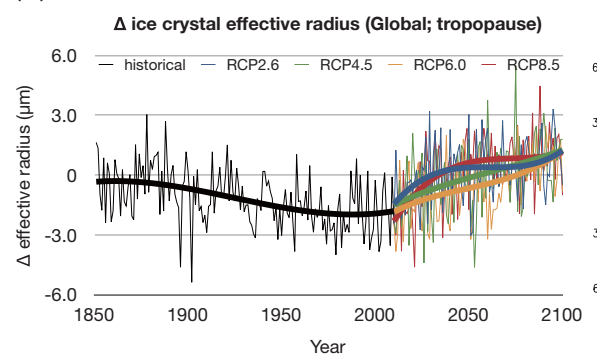

(b)

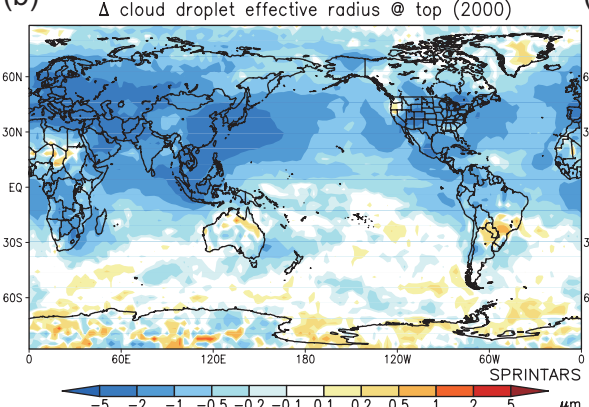

(e)

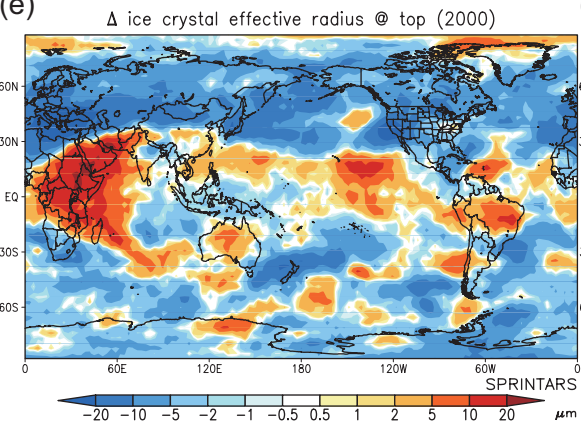

(c)

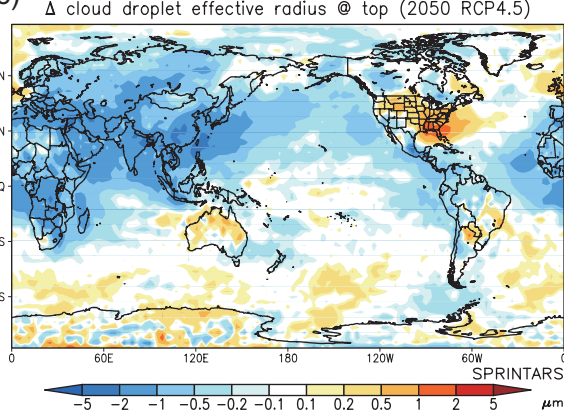

(f)

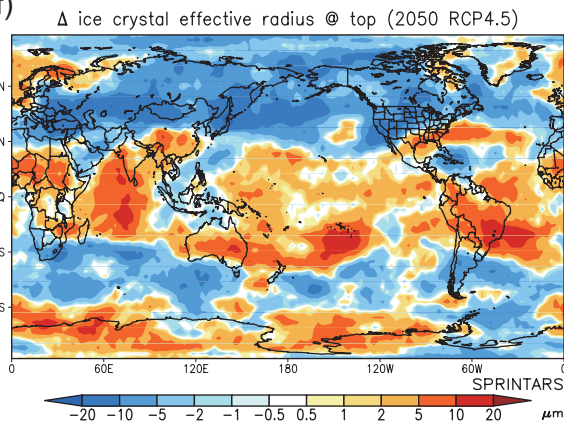

Fig. 12. Time series of annual and global mean effective radii at the cloud top of (a) cloud droplets and (d) ice crystals, and global distributions of changes in effective radii of (b) cloud droplets and (e) ice crystals in 2000 (averaged over the period 1998-2002) and (c) cloud droplets and (f) ice crystals in 2050 (averaged over the period 2048-2052) for the RCP4.5 experiment relative to the preindustrial experiment simulated by SPRINTARS. In (a) and (d), historical period is shown in black, and the four RCPs are shown in colours. In (d), thick lines are regression curves.

(a)

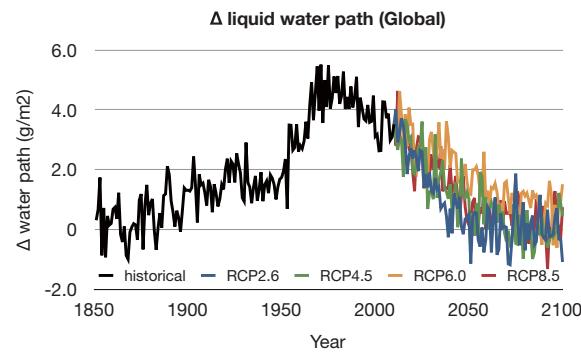

(d)

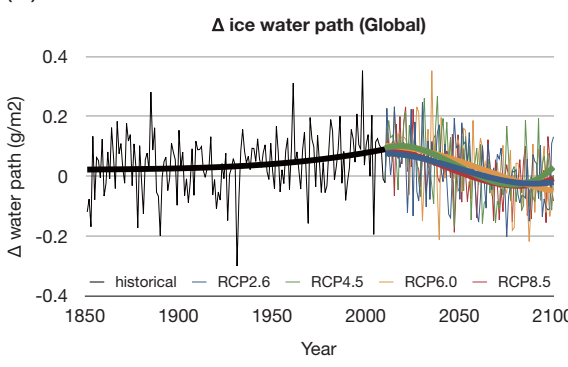

(b)

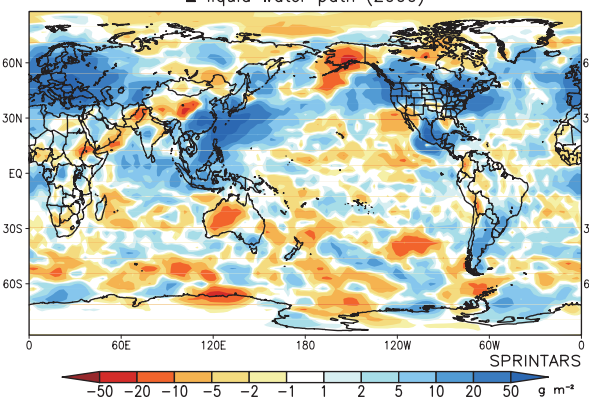

(e)

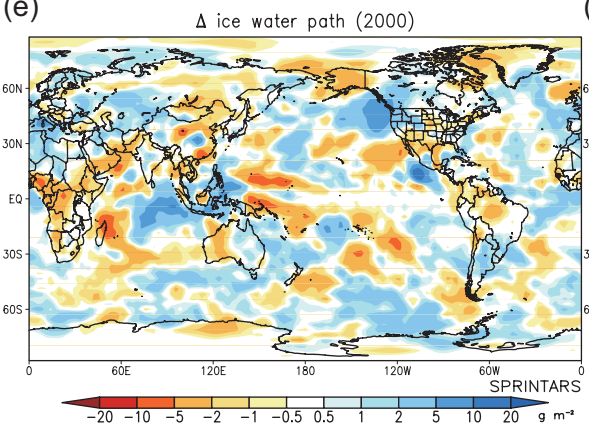

(c)

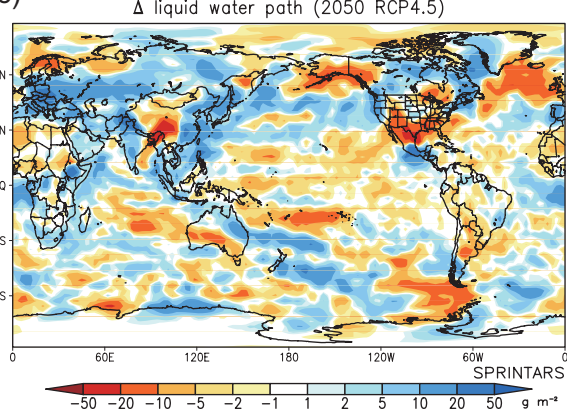

(f)

Fig. 13. Time series of changes in annual and global mean water paths of (a) liquid and (d) ice, and global distributions of changes in water paths of (b) liquid and (e) ice in 2000 (averaged over the period 1998-2002) and (c) liquid and (f) ice in 2050 (averaged over the period 2048-2052) for the RCP4.5 experiment relative to the preindustrial experiment simulated by SPRINTARS. In (a) and (d), the historical period is shown in black, and the four RCPs are shown in colours. In (d), thick lines are regression curves. 
(a) indirect adjusted forcing (Global; tropopause) 1.0

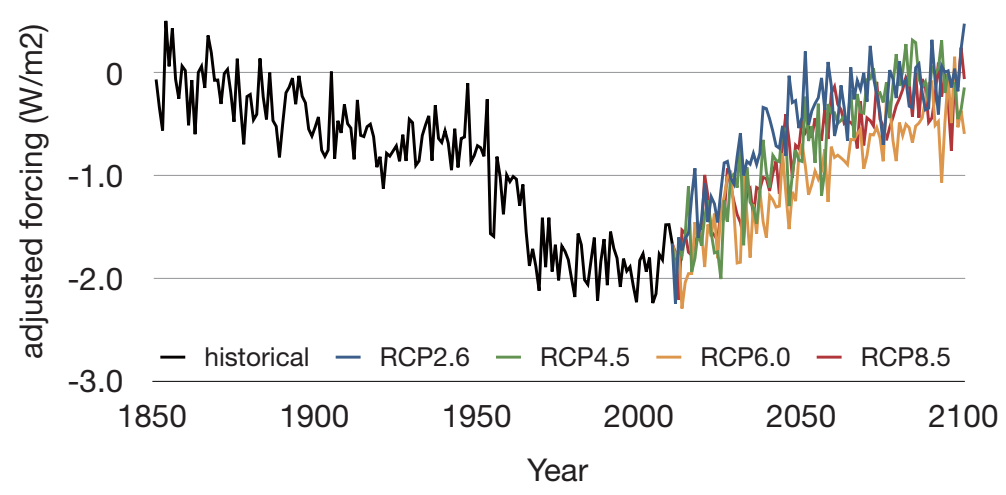

(d)

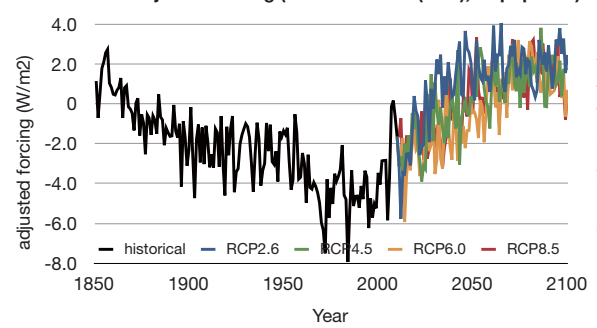

(g) indirect adjusted forcing (Africa (land); tropopause)

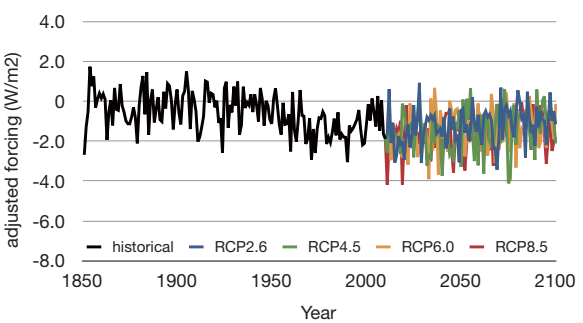

(e)

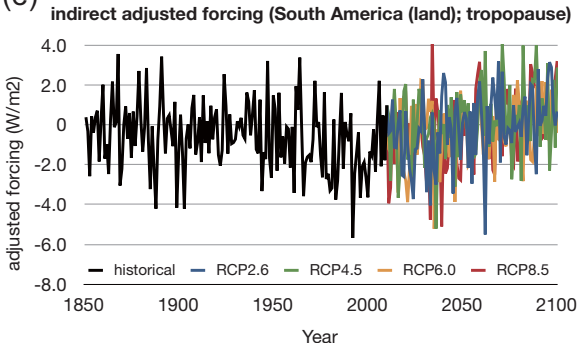

(h)

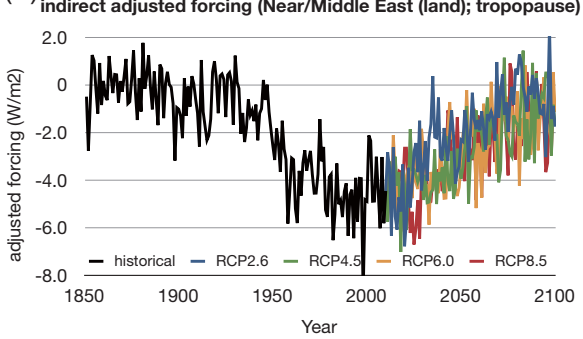

(b) indirect adjusted forcing (Asia (land); tropopause)

4.0 - historical - RCP2.6 - RCP4.5 - RCP6.0 - RCP8.5

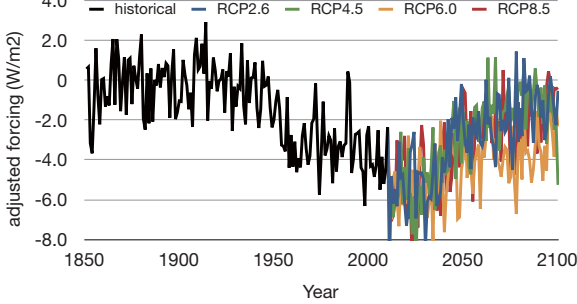

(c)
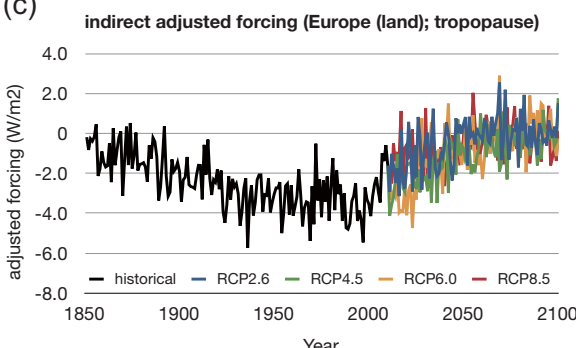

(f)

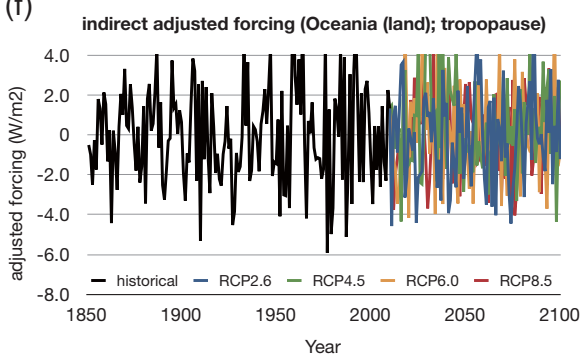

Fig. 14. Time series of changes in annual and (a) global or (b)-(h) regional mean adjusted forcing due to the aerosol indirect effect at the tropopause relative to the preindustrial experiment simulated by SPRINTARS. The regional mean values are only over land. The historical period is shown in black, and the four RCPs are shown in colours.

because the AF due to the aerosol indirect effect includes rapid responses from all aerosol effects, which affects the hydrological cycle. The global mean negative AF rapidly increases after the 1950s and then reaches a maximum of $-1.9 \mathrm{~W} \mathrm{~m}^{-2}$ in 2000 (Fig. 14a), as also shown in Table 2. Figure 15a presents the distinct current negative forcing over East and Southeast Asia, Northern Indian Ocean, Europe, west coast of Southern Africa, and North Atlantic. No large differences appear in the recovery of the global mean future AF toward zero among the different RCPs, although the negative forcing is slightly larger in RCP6.0, which has the most aerosol emissions (Fig. 2). The global mean AF due to the aerosol indirect effect is estimated to be close to zero by the end of this century. The maximum negative AF is in the 1990s for Europe and North America but is predicted to be in the 2020s for Asia (Fig. 14b-d). In North America, the AF is predicted to shift to positive values after the mid-21st century, when aerosol emissions become lower than in the mid19th century based on the RCPs described in Sect. 5. The AF due to the aerosol indirect effect still has large negative values in Asia, particularly in RCP6.0. In Africa, the future temporal variation is not predicted to be large (Fig. 14g), which is consistent with future projections of the aerosol loading in the different RCPs, as shown in Fig. 4.

Figure 16 presents the global mean AF for each aerosol component by the indirect effect until 2010 , both at the 
(a)

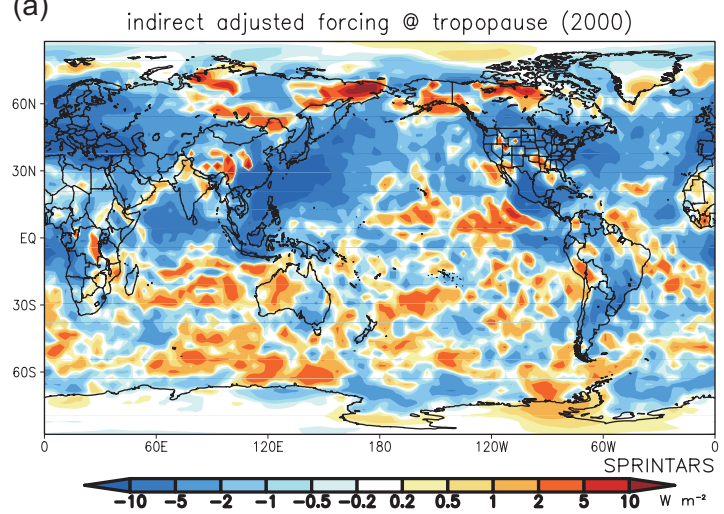

(b)

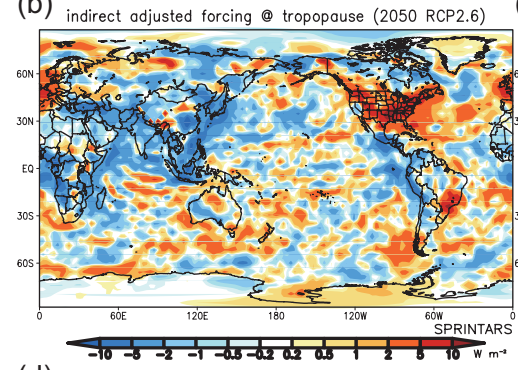

(d)

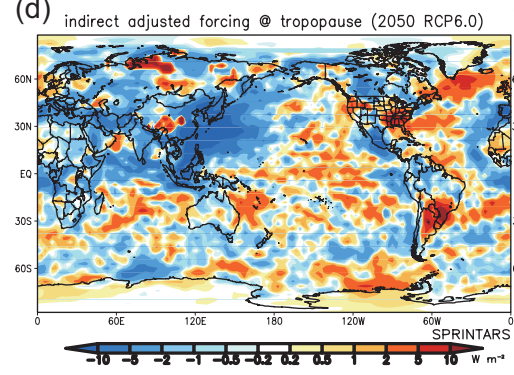

(c)

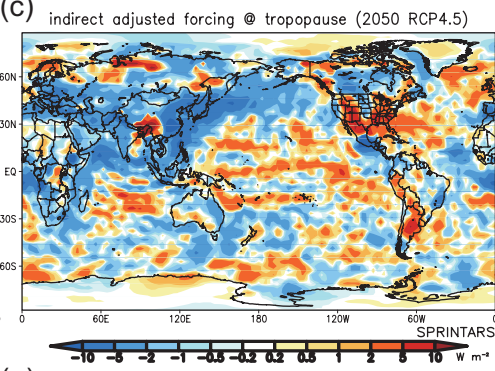

(e)

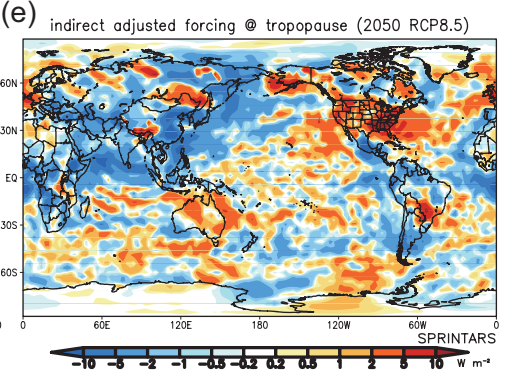

Fig. 15. Global distributions of adjusted forcing due to the aerosol indirect effect at the tropopause in (a) 2000 (averaged over the period 1998-2002) and (b)-(e) 2050 (averaged over the period 2048-2052) for the four RCPs relative to the preindustrial experiment simulated by SPRINTARS.

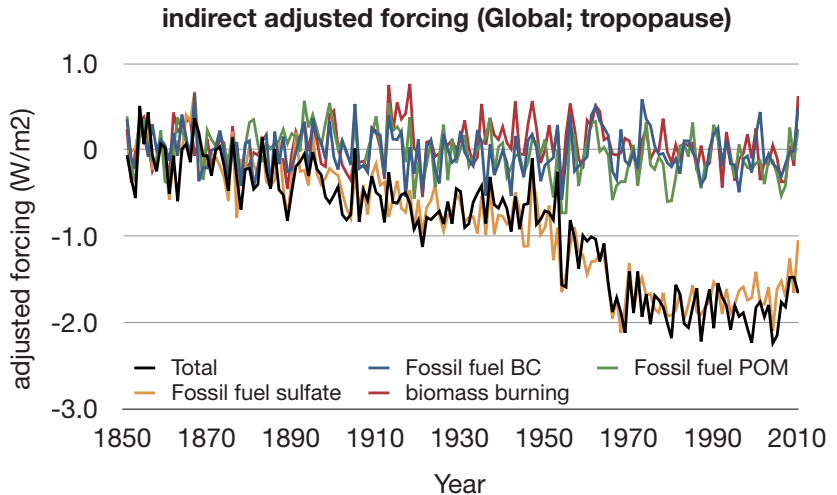

Fig. 16. Time series of annual and global mean adjusted forcing due to the indirect effect by aerosols from fossil fuel (BC, POM, and sulphate) and from biomass burning at the tropopause relative to the preindustrial experiment simulated by SPRINTARS.

tropopause and the surface. The total $\mathrm{AF}$ is almost equal to the AF due to sulphate particles which act as cloud condensation nuclei. POM from fossil fuel consumption is a minor contributor to the AF of the aerosol indirect effect. In the present MIROC-SPRINTARS simulation, BC particles are treated as ice nuclei. If $\mathrm{BC}$ emissions increase, the total (liquid + ice) cloud water decreases because of the freezing of supercooled water, which promotes growth to precipitation. In contrast, reducing the size of ice crystals can result in an obstruction of their growth if the number of ice nuclei increases. Based on the time series shown in Fig. 13e, f, it is difficult to determine which processes are dominant.
Table 2. Global mean adjusted forcing (in $\mathrm{Wm}^{-2}$ ) due to the aerosol indirect effect at the tropopause in each decade (5-yr running mean) relative to the preindustrial experiment simulated by SPRINTARS.

\begin{tabular}{lccccc}
\hline Year & Hindcast & RCP2.6 & RCP4.5 & RCP6.0 & RCP8.5 \\
\hline 1860 & -0.15 & & & & \\
1870 & -0.05 & & & & \\
1880 & -0.40 & & & & \\
1890 & -0.43 & & & & \\
1900 & -0.57 & & & & \\
1910 & -0.55 & & & & \\
1920 & -0.85 & & & & \\
1930 & -0.71 & & & & \\
1940 & -0.70 & & & & \\
1950 & -0.78 & & & & \\
1960 & -1.09 & & & & \\
1970 & -1.74 & & & & \\
1980 & -1.85 & & & & \\
1990 & -1.75 & & & & \\
2000 & -1.87 & & & & \\
2010 & & -1.69 & -1.65 & -1.63 & -1.71 \\
2020 & & -1.35 & -1.48 & -1.62 & -1.37 \\
2030 & & -0.90 & -1.09 & -1.39 & -1.36 \\
2040 & & -0.48 & -0.88 & -1.36 & -1.00 \\
2050 & & -0.30 & -0.67 & -0.97 & -0.60 \\
2060 & & -0.24 & -0.40 & -0.88 & -0.32 \\
2070 & & -0.04 & -0.17 & -0.70 & -0.48 \\
2080 & & -0.07 & +0.05 & -0.62 & -0.24 \\
2090 & & -0.17 & -0.05 & -0.28 & -0.23 \\
2100 & & +0.09 & -0.23 & -0.36 & -0.15 \\
\hline
\end{tabular}




\section{Conclusions}

In this study, the global distributions and adjusted forcing (AF) of atmospheric aerosols from the year 1850 to 2100 were simulated using the global aerosol climate model, SPRINTARS. The emission inventories of anthropogenic $\mathrm{BC}, \mathrm{POM}$, and $\mathrm{SO}_{2}$ used in the simulation were based on Lamarque et al. (2010) for the historical period and the Representative Concentration Pathways (RCPs) (Moss et al., 2010) for the future projections, which were obtained from the standard database in the Coupled Model Intercomparison Project Phase 5 (CMIP5) in conjunction with the Fifth Assessment Report (AR5) of the Intergovernmental Panel on Climate Change (IPCC). Natural aerosol emissions for soil dust particles and sea salt were calculated with parameters inside the model, which were then influenced by global warming. The regional mean aerosol loading and optical thickness reached a maximum in the 1970s to 1980s in Europe and North America, which is consistent with the global mean. In contrast, in Asia they were estimated to remain at high levels until the mid-21st century in RCP6.0 and to reach a maximum in the 2010s. A large amount of aerosols from biomass burning will be released throughout this century, according to the RCPs. Soil dust particles and sea salt emissions were predicted to increase because of the expansion of arid areas and the melting of sea ice over the Arctic region, respectively both of which are a consequence of global warming.

The AF includes the rapid response of the climate system to changes in climate forcing agents calculated for the prescribed sea surface temperature and sea ice cover. Time evolution of the AF by the aerosol direct and indirect effects typically correspond to the aerosol loading. The global mean negative AF, both at the tropopause and the surface, rapidly increased due to the aerosol direct effect after the 1950s and peaked in the 1970 s to 1990 s, a similar temporal variation to that in Europe and North America. Asia was predicted to retain a high negative $A F$ due to the direct effect until the mid-21st century in RCP6.0, which affects the time series for the global mean. The maximum negative AF due to the aerosol indirect effect was in the 1990s for Europe and North America, but was predicted to be in the 2020s for Asia. By the end of the 21 st century, aerosol forcing will be close to zero, relative to the preindustrial era, for all RCPs, and global warming is likely to accelerate under conditions of reduced aerosol negative forcing with continuous increases in greenhouse gases.

Acknowledgements. We would like to thank the developers of both SPRINTARS and MIROC. The simulation in this study was partly executed on the NEC SX-8R of the National Institute for Environmental Studies, Japan. This study was supported by the Funding Program for Next Generation World-Leading Researchers by the Cabinet Office, Government of Japan (GR079).

Edited by: A. Laaksonen

\section{References}

Abdul-Razzak, H. and Ghan, S. J.: A parameterization of aerosol activation: 2. multiple aerosol type, J. Geophys. Res., 105, 68376844, 2000.

Albrecht, B. A.: Aerosols, cloud microphysics, and fractional cloudiness, Science, 245, 1227-1230, 1989.

d'Almeida, G. A., Koepke, P., and Shettle, E.: Atmospheric Aerosols: Global Climatology and Radiative Forcing, A. Deepak, Hampton, VA, USA, 561 pp., 1991.

Andres, R. J. and Kasgnoc, A. D.: A time-averaged inventory of subaerial volcanic sulfur emissions, J. Geophys. Res., 103, 25251-25261, 1998.

Bates, T. S., Charlson, R. J., and Gammon, R. H.: Evidence for the climate role of marine biogenic sulphur, Nature, 329, 319-321, 1987.

Bellouin, N., Rae, J., Jones, A., Johnson, C., Haywood, J., and Boucher, O.: Aerosol forcing in the Climate Model Intercomparison Project (CMIP5) simulations by HadGEM2-ES and the role of ammonium nitrate, J. Geophys. Res., 116, D20206, doi:10.1029/2011JD016074, 2011.

Deepak, A. and Gerber, H. G. (Eds.): Report of the experts meeting on aerosols and their climatic effects, World Meteorological Organization, Geneva, Switzerland, Rep. WCP-55, 107 pp., 1983.

Diehl, K., Simmel, M., and Wurzler, S.: Numerical sensitivity studies on the impact of aerosol properties and drop freezing modes on the glaciation, microphysics, and dynamics of clouds, J. Geophys. Res., 111, D07202, doi:10.1029/2005JD005884, 2006.

Forster, P., Ramaswamy, V., Artaxo, P., Berntsen, T., Betts, R., Fahey, D. W., Haywood, J., Lean, J., Lowe, D. C., Myhre, G., Nganga, J., Prinn, R., Raga, G., Schulz, M., and Van Dorland, R.: Changes in atmospheric constituents and in radiative forcing, in: Climate Change 2007: The Physical Science Basis, Contribution of Working Group I to the Fourth Assessment Report of the Intergovernmental Panel on Climate Change, edited by: Solomon, S., Qin, D., Manning, M., Chen, Z., Marquis, M., Averyt, K. B., Tignor, M., and Miller, H. L., Cambridge University Press, Cambridge, UK and New York, NY, USA, 129-234, 2007.

Griffin, R. J., Cocker III, D. R., Seinfeld, J. H., and Dabdub, D.: Estimate of global atmospheric organic aerosol from oxidation of biogenic hydrocarbons, Geophys. Res. Lett., 26, 2721-2724, 1999.

Guenther, A., Hewitt, C. N., Erickson, D., Fall, R., Geron, C., Graedel, T., Harley, P., Klinger, L., Lerdau, M., McKay, W. A., Pierce, T., Scholes, B., Steinbrecher, R., Tallamraju, R., Taylor, J., and Zimmerman, P.: A global model of natural volatile organic compound emissions, J. Geophys. Res., 100, 8873-8892, 1995.

Hansen, J., Sato, M., Nazarenko, L., Ruedy, R., Lacis, A., Koch, D., Tegen, I., Hall, T., Shindell, D., Santer, B., Stone, P., Novakov, T., Thomason, L., Wang, R., Wang, Y., Jacob, D., Hollandsworth, S., Bishop, L., Logan, J., Thompson, A., Stolarski, R., Lean, J., Willson, R., Levitus, S., Antonov, J., Rayner, N., Parker, D., and Christy, J.: Climate forcings in Goddard Institute for Space Studies SI2000 simulations, J. Geophys. Res., 107, 4347, doi:10.1029/2001JD001143, 2002.

Haywood, J. M. and Ramaswamy, V.: Global sensitivity studies of the direct radiative forcing due to anthropogenic sulfate and black carbon aerosols, J. Geophys. Res., 103, 6043-6058, 1998. 
Horowitz, L. W.: Past, present, and future concentrations of tropospheric ozone and aerosols: Methodology, ozone evaluation, and sensitivity to aerosol wet removal, J. Geophys. Res., 111, D22211, doi:10.1029/2005JD006937, 2006.

Intergovernmental Panel on Climate Change: Climate Change 2007: The Physical Science Basis, Contribution of Working Group I to the Fourth Assessment Report of the Intergovernmental Panel on Climate Change, edited by: Solomon, S., Qin, D., Manning, M., Chen, Z., Marquis, M., Averyt, K. B., Tignor, M., and Miller, H. L., Cambridge University Press, Cambridge, UK and New York, NY, USA, 996 pp., 2007.

Kärcher, B. and Lohmann, U.: A parameterization of cirrus cloud formation: Homogeneous freezing of supercooled aerosols, J. Geophys. Res., 107, 4010, doi:10.1029/2001JD000470, 2002.

Kinne, S., Lohmann, U., Feichter, J., Schulz, M., Timmreck, C., Ghan, S., Easter, R., Chin, M., Ginoux, P., Takemura, T., Tegen, I., Koch, D., Herzog, M., Penner, J., Pitari, G., Holben, B., Eck, T., Smirnov, A., Dubovik, O., Slutsker, I., Tanre, D., Torres, O., Mishchenko, M., Geogdzhayev, I., Chu, A., and Kaufman, Y.: Monthly averages of aerosol properties: a global comparison among models, satellite data and AERONET ground data, J. Geophys. Res., 108, 4634, doi:10.1029/2001JD001253, 2003.

Kloster, S., Mahowald, N. M., Randerson, J. T., and Lawrence, P. J.: The impacts of climate, land use, and demography on fires during the 21 st century simulated by CLM-CN, Biogeosciences, 9, 509525, doi:10.5194/bg-9-509-2012, 2012.

Koch, D. and Del Genio, A. D.: Black carbon semi-direct effects on cloud cover: review and synthesis, Atmos. Chem. Phys., 10, 7685-7696, doi:10.5194/acp-10-7685-2010, 2010.

Lamarque, J.-F., Bond, T. C., Eyring, V., Granier, C., Heil, A., Klimont, Z., Lee, D., Liousse, C., Mieville, A., Owen, B., Schultz, M. G., Shindell, D., Smith, S. J., Stehfest, E., Van Aardenne, J., Cooper, O. R., Kainuma, M., Mahowald, N., McConnell, J. R., Naik, V., Riahi, K., and van Vuuren, D. P.: Historical (1850???2000) gridded anthropogenic and biomass burning emissions of reactive gases and aerosols: methodology and application, Atmos. Chem. Phys., 10, 7017-7039, doi:10.5194/acp10-7017-2010, 2010.

Lebsock, M. D., Stephens, G. L., and Kummerow, C.: Multisensor satellite observations of aerosol effects on warm clouds, J. Geophys. Res., 113, D15205, doi:10.1029/2008JD009876, 2008.

Lohmann, U.: A glaciation indirect aerosol effect caused by soot aerosols, Geophys. Res. Lett., 29, 1052, doi:10.1029/2001GL014357, 2001.

Lohmann, U. and Diehl, K.: Sensitivity studies of the importance of dust ice nuclei for the indirect aerosol effect on stratiform mixedphase clouds, J. Atmos. Sci., 63, 968-982, 2006.

Lohmann, U. and Feichter, J.: Global indirect aerosol effects: a review, Atmos. Chem. Phys., 5, 715-737, doi:10.5194/acp-5-7152005, 2005.

Monahan, E. C., Spiel, D. E., and Davidson, K. L.: A model of marine aerosol generation via whitecaps and wave disruption, in: Oceanic Whitecaps, edited by: Monahan, E., Niocaill, G. M., and Reidel, D., Norwell, Mass., USA, 167-174, 1986.

Moss, R. H., Edmonds, J. A., Hibbard, K. A., Manning, M. R., Rose, S. K., van Vuuren, D. P., Carter, T. R., Emori, S., Kainuma, M., Kram, T., Meehl, G. A., MItchell, F. B., Nakicenovic, N., Riahi, K., Smith, S. J., Stouffer, R. J., Thomson, A. M.,
Weyant, J. P., and Wilbanks, T. J.: The next generation of scenarios for climate change research and assessment, Nature, 463, 747-756, doi:10.1038/nature08823, 2010.

Myhre, G., Myhre, A., and Stordal, F.: Historical evolution of radiative forcing of climate, Atmos. Environ., 35, 2361-2373, 2001.

Myhre, G., Berglen, T. F., Johnsrud, M., Hoyle, C. R., Berntsen, T. K., Christopher, S. A., Fahey, D. W., Isaksen, I. S. A., Jones, T. A., Kahn, R. A., Loeb, N., Quinn, P., Remer, L., Schwarz, J. P., and Yttri, K. E.: Modelled radiative forcing of the direct aerosol effect with multi-observation evaluation, Atmos. Chem. Phys., 9, 1365-1392, doi:10.5194/acp-91365-2009, 2009.

Nozawa, T., Nagashima, T., Shiogama, H., and Crooks, S. A.: Detecting natural influence on surface air temperature change in the early twentieth century, Geophys. Res. Lett., 32, L20719, doi:10.1029/2005GL023540, 2005.

Pechony, O., and Shindell, D. T.: Driving forces of global wildfires over the past millennium and the forthcoming century, Proc. Natl. A. Sci., 107, 19167-19170, doi:10.1073/pnas.1003669107, 2010.

Quaas, J., Ming, Y., Menon, S., Takemura, T., Wang, M., Penner, J. E., Gettelman, A., Lohmann, U., Bellouin, N., Boucher, O., Sayer, A. M., Thomas, G. E., McComiskey, A., Feingold, G., Hoose, C., Kristjánsson, J. E., Liu, X., Balkanski, Y., Donner, L. J., Ginoux, P. A., Stier, P., Grandey, B., Feichter, J., Sednev, I., Bauer, S. E., Koch, D., Grainger, R. G., Kirkevåg, A., Iversen, T., Seland, Õ., Easter, R., Ghan, S. J., Rasch, P. J., Morrison, H., Lamarque, J.-F., Iacono, M. J., Kinne, S., and Schulz, M.: Aerosol indirect effects - general circulation model intercomparison and evaluation with satellite data, Atmos. Chem. Phys., 9, 8697-8717, doi:10.5194/acp-98697-2009, 2009.

Science: U. S. Tweets Chinese Air Quality, Science, 336, p. 787, 2012.

Sekiguchi, M. and Nakajima, T.: A $k$-distribution-based radiation code and its computational optimization for an atmospheric general circulation model, J. Quant. Spectrosc. Ra., 109, 2779-2793, 2008.

Skeie, R. B., Berntsen, T. K., Myhre, G., Tanaka, K., Kvalevåg, M. M., and Hoyle, C. R.: Anthropogenic radiative forcing time series from pre-industrial times until 2010 , Atmos. Chem. Phys., 11, 11827-11857, doi:10.5194/acp-1111827-2011, 2011.

Spiro, P. A., Jacob, D. J., and Logan, J. A.: Global inventory of sulfur emissions with $1^{\circ} \times 1^{\circ}$ resolution, J. Geophys. Res., 97, 6023-6036, 1992.

Sudo, K., Takahashi, M., Kurokawa, J., and Akimoto, H.: CHASER: a global chemical model of the troposphere: 1. model description, J. Geophys. Res., 107, 4339, doi:10.1029/2001JD001113, 2002.

Takemura, T., Okamoto, H., Maruyama, Y., Numaguti, A., Higurashi, A., and Nakajima, T.: Global three-dimensional simulation of aerosol optical thickness distribution of various origins, J. Geophys. Res., 105, 17853-17873, 2000.

Takemura, T., Nakajima, T., Dubovik, O., Holben, B. N., and Kinne, S.: Single-scattering albedo and radiative forcing of various aerosol species with a global three-dimensional model, J. Climate, 15, 333-352, 2002a. 
Takemura, T., Uno, I., Nakajima, T., Higurashi, A., and Sano, I.: Modeling study of long-range transport of Asian dust and anthropogenic aerosols from East Asia, Geophys. Res. Lett., 29, 2158, doi:10.1029/2002GL016251, 2002b.

Takemura, T., Nakajima, T., Higurashi, A., Ohta, S., and Sugimoto, N.: Aerosol distributions and radiative forcing over the Asian-Pacific region simulated by spectral radiation-transport model for aerosol species (SPRINTARS), J. Geophys. Res., 108, 8659, doi:10.1029/2002JD003210, 2003.

Takemura, T., Nozawa, T., Emori, S., Nakajima, T. Y., and Nakajima, T.: Simulation of climate response to aerosol direct and indirect effects with aerosol transport-radiation model, J. Geophys. Res., 110, D02202, doi:10.1029/2004JD005029, 2005.

Takemura, T., Tsushima, Y., Yokohata, T., Nozawa, T., Nagashima, T., and Nakajima, T.: Time evolutions of various radiative forcings for the past $150 \mathrm{yr}$ estimated by a general circulation model, Geophys. Res. Lett., 33, L19705, doi:10.1029/2006GL026666, 2006.

Takemura, T., Egashira, M., Matsuzawa, K., Ichijo, H., O'ishi, R., and Abe-Ouchi, A.: A simulation of the global distribution and radiative forcing of soil dust aerosols at the Last Glacial Maximum, Atmos. Chem. Phys., 9, 3061-3073, doi:10.5194/acp-93061-2009, 2009.

Takemura, T. and Uchida, T.: Global climate modeling of regional changes in cloud, precipitation, and radiation budget due to the aerosol semi-direct effect of black carbon, SOLA, 7, 181-184, doi:10.2151/sola.2011-046, 2011.
Textor, C., Schulz, M., Guibert, S., Kinne, S., Balkanski, Y., Bauer, S., Berntsen, T., Berglen, T., Boucher, O., Chin, M., Dentener, F., Diehl, T., Easter, R., Feichter, H., Fillmore, D., Ghan, S., Ginoux, P., Gong, S., Grini, A., Heqndricks, J., Horowitz, L., Huang, P., Isaksen, I., Iversen, I., Kloster, S., Koch, D., Kirkevåg, A., Kristjansson, J. E., Krol, M., Lauer, A., Lamarque, J. F., Liu, X., Montanaro, V., Myhre, G., Penner, J., Pitari, G., Reddy, S., Seland, Ø., Stier, P., Takemura, T., and Tie, X.: Analysis and quantification of the diversities of aerosol life cycles within AeroCom, Atmos. Chem. Phys., 6, 1777-1813, doi:10.5194/acp-6-1777-2006, 2006.

Twomey, S.: Pollution and the planetary albedo, Atmos. Environ., 8, 1251-1256, 1974.

Washington Post: Beijing makes rare concession on pollution measure, http://www.washingtonpost.com/world/asia_pacific/ beijing-makes-rare-concession-on-pollution-measure/2012/01/ 19/gIQApsI6BQ_story.html, by: Richburg, K. B., last access: 4 December 2012.

Watanabe, M., Suzuki, T., O'ishi, R., Komuro, Y., Watanabe, S., Emori, S., Takemura, T., Chikira, M., Ogura, T., Sekiguchi, M., Takata, K., Yamazaki, D., Yokohata, T., Nozawa, T., Hasumi, H., Tatebe, H., and Kimoto, M.: Improved climate simulation by MIROC5: mean states, variability, and climate sensitivity, J. Climate, 23, 6312-6335, doi:10.1175/2010JCLI3679.1, 2010.

Yamaguchi, Y. and Takemura, T.: Time evolution of integrated observational times of smog and Asian dust, Tenki (in Japanese), 58, 965-968, available at: http://www.metsoc.jp/tenki/pdf/2011/ 2011_11_0029.pdf, 2011. 